\title{
Kengetallen voor het personeelsbeleid in de rijksdienst
}

Citation for published version (APA):

van der Velden, R. K. W. (1994). Kengetallen voor het personeelsbeleid in de rijksdienst.

Researchcentrum voor Onderwijs en Arbeidsmarkt, Faculteit der Economische Wetenschappen. ROA Reports No. 5 https://doi.org/10.26481/umarep.1994005

Document status and date:

Published: 01/01/1994

DOI:

10.26481/umarep.1994005

Document Version:

Publisher's PDF, also known as Version of record

\section{Please check the document version of this publication:}

- A submitted manuscript is the version of the article upon submission and before peer-review. There can be important differences between the submitted version and the official published version of record.

People interested in the research are advised to contact the author for the final version of the publication, or visit the DOI to the publisher's website.

- The final author version and the galley proof are versions of the publication after peer review.

- The final published version features the final layout of the paper including the volume, issue and page numbers.

Link to publication

\footnotetext{
General rights rights.

- You may freely distribute the URL identifying the publication in the public portal. please follow below link for the End User Agreement:

www.umlib.nl/taverne-license

Take down policy

If you believe that this document breaches copyright please contact us at:

repository@maastrichtuniversity.nl

providing details and we will investigate your claim.
}

Copyright and moral rights for the publications made accessible in the public portal are retained by the authors and/or other copyright owners and it is a condition of accessing publications that users recognise and abide by the legal requirements associated with these

- Users may download and print one copy of any publication from the public portal for the purpose of private study or research.

- You may not further distribute the material or use it for any profit-making activity or commercial gain

If the publication is distributed under the terms of Article $25 \mathrm{fa}$ of the Dutch Copyright Act, indicated by the "Taverne" license above, 
KENGETALLEN VOOR HET PERSONEELSBELEID

IN DE RIJKSDIENST

ROA-R-1994/5

R.K.W. van der Velden

RESEARCHCENTRUM VOOR ONDERWIJS EN ARBEIDSMARKT

Faculteit der Economische Wetenschappen

Rijksuniversiteit Limburg

Maastricht, mei 1994 


\section{CIP-GEGEVENS KONINKLIJKE BIBLIOTHEEK, DEN HAAG}

Velden, R.K.W. van der

Kengetallen voor het personeelsbeleid in de rijksdienst / R.K.W. van der Velden. - Maastricht : Researchcentrum voor Onderwijs en Arbeidsmarkt, Faculteit der Economische Wetenschappen, Rijksuniversiteit Limburg. ([Rapport] / Researchcentrum voor Onderwijs en Arbeidsmarkt, ISSN 0922-8098; ROA-R-1994/5)

ISBN 90-5321-132-2 geb.

Trefw.: personeelsbeleid ; overheid. 


\section{INHOUDSOPGAVE}

Bladzijde

$\begin{array}{ll}\text { 1. INLEIDING } & 1\end{array}$

2. KENGETALLEN VOOR HET PERSONEELSBELEID 2

3. HET MEETNIVEAU VAN DE GEGEVENS 4

4. DATAREDUCTIE 5

4.1. Het centrum van een verdeling 5

4.1.1. Gemiddelde 5

4.1.2. Mediaan 6

4.2. De spreiding van een verdeling 8

4.2.1. Standaardafwijking $\quad 8$

4.2.2. Coëfficiënt van relatieve variatie 9

4.2.3. Scheefheid 10

4.2.4. Kurtosis 11

4.2.5. Gini-Hirschmann coëfficiënt 13

4.3. Ontwikkelingen in de tijd 15

4.3.1. Groeivoet 15

4.3.2. Fluctuatie-index 16

$\begin{array}{ll}\text { 4.3.3. Ontwikkelingsindex } & 17\end{array}$

5. ANALYSES 18

5.1. Gelijkheid 18

5.2. Segregatie-index 19

5.3. Afwijkingsindex 20

5.4. Shift-share analyse $\quad 21$

6. SCENARIO 24

7. PERSONEELSINDICATOREN 26

7.1. Structurele promotiekansen 26

$\begin{array}{ll}\text { 7.2. Personeelsturnover } & 27\end{array}$

$\begin{array}{lr}\text { 7.3. Uitbreidings- en vervangingsvraag } & 29\end{array}$

$\begin{array}{ll}\text { 7.4. Performance indicator } & 31\end{array}$

8. AFBEELDINGEN 33

8.1. Functie-opbouw 33

8.2. Promotiekokers 33

8.3. Afwijkingen van het gemiddelde $\quad 35$

8.4. Multi Dimensional Scaling 35

8.5. Lorenz-curve 36

BIJLAGE 1. ANDERE PERSONEELSINDICATOREN 38 


\section{INLEIDING}

De Directie Personeelsmanagement Rijksdienst van het Ministerie van Binnenlandse Zaken gaf vanaf 1988 jaarlijks de publicatie 'Overheid en Arbeidsmarkt' uit, in 1994 opgevolgd door 'Mensen en Management in de rijksdienst'. Hierin wordt cijfermateriaal gepresenteerd met betrekking tot de werkgelegenheid bij de rijksdienst. In een aantal min of meer vaste hoofdstukken komen jaarlijks dezelfde rubrieken aan de orde met betrekking tot: ontwikkelingen in in- en uitstroom, mobiliteit, leeftijdsopbouw, man/vrouwverhouding, minderheden etc. Vanaf 1992 wordt deze informatie aangevuld met meer algemene gegevens over ontwikkelingen op de arbeidsmarkt.

Het jaarboek voorziet zowel binnen als buiten de overheidssector in de grote behoefte die er bestaat aan kwantitatieve gegevens over de werkenden binnen de rijksoverheid. De gepresenteerde gegevens laten een grote mate van detaillering toe naar de verschillende diensten en omvatten bovendien in de regel een onderverdeling naar geslacht, leeftijdsklasse, BBRA-schaal en werktijd.

De behoefte bestaat om deze gegevens aan te vullen met indicatoren of kengetallen die op een meer inzichtelijke wijze trends of relaties weergeven. Dergelijke kengetallen kunnen vervolgens gebruikt worden in het personeels- en organisatiebeleid. Van belang daarbij is dat met ingang van 1994 sterker dan voorheen de nadruk zal komen te liggen op de sector rijkspersoneel, dat wil zeggen de ministeries exclusief defensiepersoneel. Anderzijds zal er een uitbreiding plaatsvinden van gegevens die betrekking hebben op het gebied van de arbeidsvoorwaarden en het formatiebeheer. Gestreefd wordt naar een jaarlijkse rapportage die betrekking heeft op een onderling samenhangend geheel van bedrijfsvoering, management en personeelsbeleid. Hierbij wordt een beroep gedaan op de informatie die beschikbaar komt via het in 1991 gestarte project personeelsinformatievoorziening (PIV).

Het Researchcentrum voor Onderwijs en Arbeidsmarkt (ROA) is gevraagd om voorstellen te ontwikkelen op welke wijze de grote hoeveelheid gegevens kan worden gereduceerd tot een beperkt aantal kengetallen. Het project is uitgevoerd door dr. R.K.W. van der Velden. Assistentie is verleend door drs. R.J.P. Dekker en M. Reiners. Het project is vanuit het Ministerie van Binnenlandse Zaken begeleid door drs. G.W. Kreffer. 


\section{KENGETALLEN VOOR HET PERSONEELSBELEID}

Personeel vormt het menselijk kapitaal van een arbeidsorganisatie. Voor een arbeidsintensieve sector als de rijksdienst is het zelfs de belangrijkste vorm van kapitaal waar het over beschikt. De inzet van deze vorm van kapitaal is daarom een belangrijk beleidsinstrument en kennis over het personeel is onontbeerlijk voor een adequaat management.

Toch is de kennis op managementniveau over het menselijk kapitaal van de organisatie in de regel slechts fragmentarisch aanwezig. Weliswaar is door de automatisering van personeelsinformatiesystemen een belangrijke databron beschikbaar gekomen, maar deze gegevens worden vooralsnog hoofdzakelijk gebruikt als dossier over individuele personeelsleden of als statistiek ten behoeve van beschrijvende doeleinden.

Wil men informatie uit een personeelsinformatiesysteem gebruiken ten behoeve van het personeels- en organisatiebeleid, dan moet in ieder geval aan twee eisen worden voldaan. Op de eerste plaats moet een zinvolle reductie van gegevens plaatsvinden. De overvloed aan gegevens die aanwezig is, moet eerst bewerkt worden om zinvol te kunnen worden toegepast als kengetal voor het personeelsbeleid. Zo heeft een gedetailleerde weergave van de leeftijdsverdeling van het personeel wel een belangrijk waarde als statistiek, maar om er een kengetal voor het personeelsbeleid van te maken is het nodig om de grote hoeveelheid informatie tot overzichtelijke proporties terug te brengen.

Op de tweede plaats moet men voor ogen houden dat kengetallen uitsluitend zinvol geïnterpreteerd kunnen worden wanneer ze in verband gebracht kunnen worden met relevante doelstellingen van dit beleid. Dat betekent dat de keuze van mogelijke kengetallen betrekking moet hebben op díe terreinen die voor het personeels- en organisatiebeleid relevant zijn, zoals mobiliteit, man/vrouwverhouding, minderheden, leeftijdsopbouw en ziekteverzuim.

In dit verslag wordt een aantal voorstellen gepresenteerd om de rijke informatie die bij de rijksdienst aanwezig is te bewerken tot relevante kengetallen. De voorstellen hebben betrekking op vijf onderdelen:

* Eerst wordt in hoofdstuk 4 een aantal statistische maten gepresenteerd om een grote hoeveelheid gegevens in meer gecomprimeerde vorm weer te geven. Hierbij gaat het dus om datareductie. Daarbij wordt geprobeerd om de kenmerken van een verdeling in én of meerdere indicatoren te beschrijven (b.v. hoe scheef is de verdeling naar leeftijd of hoe stabiel is de groei in de werkgelegenheid?).

* Vervolgens wordt in hoofdstuk 5 een aantal technieken gepresenteerd die betrekking hebben op data-analyse. Hierbij vindt niet alleen een reductie van gegevens plaats, maar wordt tevens getracht om deze gegevens in perspectief te zetten, bijvoorbeeld door aan te geven wat de samenhang is met andere gegevens of door aan te geven wat de verschillen zijn tussen twee of meer verdelingen (b.v. zijn mannen en vrouwen gelijkelijk verdeeld over de BBRA-schalen of hangt de groei in deeltijd samen met de groei in het aantal vrouwelijke personeelsleden?)

* Bij zowel datareductie als data-analyse gaat het om een bewerking van bestaande gegevens. 
Een volgende stap betreffen de scenario's (hoofdstuk 6). Hierbij worden op grond van een aantal vooronderstellingen mogelijke toekomstige ontwikkelingen bepaald. Scenario's kunnen met name gebruikt worden om alternatieve beleidsopties op hun gevolgen door te rekenen. Een voorbeeld wordt gepresenteerd met betrekking tot het promotiebeleid.

* Vervolgens wordt een aantal personeelsindicatoren gepresenteerd (hoofdstuk 7). Hierbij gaat het om grootheden die een bepaalde relatie uitdrukken of een statistische waarde die van belang is voor het personeelsbeleid. Voorbeelden hiervan zijn bepaalde verhoudingsgetallen, zoals de personeelsturnover of de vervangingsvraag.

* Tenslotte wordt in hoofdstuk 8 een aantal mogelijkheden voor grafische presentatie geschetst. Deze komt tegemoet aan de behoefte die er bestaat om de gepresenteerde informatie inzichtelijker weer te geven. Daarbij worden de gegevens zelf niet veranderd, maar wel de weergave ervan. Voorbeelden betreffen de functie-opbouw en Multi Dimensional Scaling.

Het uitgangspunt bij de selectie van technieken en indicatoren is dat deze in de toekomst op relatief eenvoudige wijze door de betreffende personeelsafdelingen van Ministeries zelf te berekenen zijn. Dat betekent dat is afgezien van technieken die de toepassing van statistische software vereisen.

De beschrijving van de statistische maten en technieken volgt een vast patroon. Eerst wordt een definitie gegeven en een toelichting op de gebruiksmogelijkheden. Daarna volgt een beschrijving van de wijze waarop de indicatoren berekend worden. In veel gevallen wordt de constructie van de indicatoren geillustreerd aan de hand van cijfers uit het jaarboek 1993 of eerdere jaarboeken.

De mogelijkheden om gegevens te bewerken en analyseren worden deels begrensd door het meetniveau van de gegevens. Voorafgaand aan de beschrijving van de statistische technieken en kengetallen, wordt daarom een uiteenzetting gegeven van de verschillende te onderscheiden meetniveaus. 


\section{HET MEETNIVEAU VAN DE GEGEVENS}

De gegevens die men wil bewerken of analyseren kunnen variëren in de mate waarin ze gekwantificeerd kunnen worden. Men spreekt in dat verband ook wel van verschillen in meetniveau. Er kunnen vier verschillende meetniveaus onderscheiden worden.

Bij nominaal meetniveau wordt geen enkele veronderstelling gemaakt over de waarden van de categorieën van een kenmerk. De categorieën worden aangeduid door een naam. Zo bestaat het kenmerk 'geslacht' uit de categorieën 'man' en 'vrouw'. Andere voorbeelden van categorieën met een nominaal meetniveau zijn 'ministerie', 'provincie', e.d.

Bij ordinaal meetniveau wordt verondersteld dat de categorieën van een kenmerk geordend kunnen worden van laag naar hoog. Een voorbeeld van een ordinaal meetniveau is de BBRAschaal. De categorieën van deze schaal kunnen geordend worden van laag naar hoog. Er wordt bij ordinaal meetniveau geen nadere veronderstelling gemaakt over de afstanden tussen de categorieën. Het verschil tussen schaal 5 en 6 hoeft niet hetzelfde te zijn als het verschil tussen schaal 9 en 10.

Bij kenmerken met een interval meetniveau wordt niet alleen verondersteld dat de categorieën geordend kunnen worden, maar wordt ook een veronderstelling gemaakt over de afstanden tussen de categorieën. Deze moeten aan elkaar gelijk zijn. Een voorbeeld betreft het jaartal. De 'afstand' tussen 1986 en 1987 is even groot als de 'afstand' tussen 1993 en 1994. Kenmerken met een interval meetniveau hebben geen betekenisvol nulpunt. Abstraherend van de verschillende nulpunten in de jaartelling die door de verschillende geloofsovertuigingen en culturen worden onderscheiden, kunnen er daarom geen zinvolle ratio's berekend worden. Men kan bijvoorbeeld niet zeggen dat het jaartal 2000 twee keer zo groot is als het jaartal 1000 .

Kenmerken met een ratio meetniveau maken niet alleen een veronderstelling over de ordening van categorieën en de afstanden tussen de categorieën, maar kennen ook een vast nulpunt. Een voorbeeld betreft leeftijd. Men kan zeggen dat iemand van 60 twee keer zo oud is als iemand van 30 . Andere voorbeelden zijn lengte of inkomen in guldens.

In de ordening van de meetniveaus kan men een zekere hiërarchie ontdekken. Het nominale meetniveau stelt helemaal geen eisen aan de categoriën van het kenmerk. Het ordinale meetniveau veronderstelt dat ze geordend kunnen worden. Het interval meetniveau veronderstelt een ordening plus vaste afstanden. Het ratio meetniveau veronderstelt ordening plus vaste afstanden plus een vast nulpunt.

Kenmerken die verschillen in meetniveau, verschillen in de manier waarop ze bewerkt kunnen worden. Sommige statistische technieken kunnen uitsluitend bij kenmerken van interval of ratio niveau worden gebruikt, andere vereisen minimaal ordinaal meetniveau. In het algemeen kan men zeggen dat een techniek die geschikt is voor een bepaald meetniveau (b.v. ordinaal meetniveau), ook geschikt is voor kenmerken met een hoger meetniveau (i.c. interval en ratio), maar niet voor een kenmerk met een lager meetniveau (i.c. nominaal). Wel zal bij het gebruiken van een dergelijke techniek bij kenmerken met een hoger meetniveau informatie verloren gaan. Het is daarom van belang om eerst goed te kijken wat het meetniveau is van de kenmerken die men wil bewerken om daar vervolgens de bijpassende bewerkingstechniek bij te zoeken. Bij de komende presentatie van datareductie en- bewerkingstechnieken zal telkens aangegeven worden wat het vereiste meetniveau is. 


\section{DATAREDUCTIE}

Veel gegevens in het jaarboek hebben betrekking op de verdeling van één specifiek kenmerk van het personeel in overheidsdienst, bijvoorbeeld de verdeling naar leeftijd of de verdeling naar BBRA-niveau. Nu zou men deze verdeling volledig kunnen beschrijven door een tabel te presenteren waarin voor elke leeftijdscategorie het bijbehorende aantal personeelsleden wordt gegeven. Een dergelijke tabel zou al gauw onoverzichtelijk worden, zelfs wanneer men de leeftijd zou indelen in bijvoorbeeld 5 -jaarsklassen. Met name wanneer men de verdelingen van meerdere organisaties of in verschillende tijdsperioden onderling wilt vergelijken, is datareductie noodzakelijk. Daarbij wordt naar specifieke kenmerken van de verdeling gekeken. Zo kan men de ontwikkeling van de leeftijdsverdeling het beste volgen door te kijken naar de ontwikkelingen van bijvoorbeeld het gemiddelde of de spreiding van de verdeling.

We onderscheiden in dit verband een drietal verschillende statistische maten: maten die het centrum of zwaartepunt van een verdeling beschrijven, maten die de spreiding van een verdeling beschrijven en maten die de ontwikkeling in de tijd beschrijven.

\subsection{Het centrum van een verdeling}

\subsubsection{Gemiddelde}

\section{Definitie:}

Het gemiddelde is gelijk aan de som van de waarden voor de verschillende waarnemingen, gedeeld door het aantal waarnemingen.

In formule:

$\mathrm{X}=\frac{1}{n} \sum_{i=1}^{n} x_{i}$

waarbij:

$\bar{X}=$ het gemiddelde van kenmerk $X$

$x_{i}=$ de waarde van kenmerk $X$ voor waarneming $i$

$\mathrm{n}=$ het aantal waarnemingen

${ }^{\mathrm{n}}$ betekent dat sommatie plaatsvindt over alle waarnemingen 1 tot en met $\mathrm{n}$

In veel gevallen zal het aantal waarnemingen te groot zijn om het gemiddelde op eenvoudige wijze te kunnen berekenen, of heeft men alleen de beschikking over gegroepeerde gegevens (bijvoorbeeld de frequentieverdeling naar leeftijdsklassen). In dat geval kan men het gemiddelde over de gegroepeerde gegevens berekenen.

In formule:

$X=\sum_{i=1}^{m} x_{i}\left(\frac{f_{i}}{n}\right)$

waarbij:

$\bar{X} \quad=$ het gemiddelde van kenmerk $X$

$\mathrm{x}_{\mathrm{i}} \quad=$ de middelste waarde van klasse $\mathrm{i}$ 
$\mathrm{f}_{\mathrm{i}} \quad=$ de frequentie in klasse $\mathrm{i}$

$\mathrm{n} \quad=$ het aantal waarnemingen

$\mathrm{m} \quad=$ het aantal klassen

$\mathrm{f}_{\mathrm{i}} / \mathrm{n} \quad=$ relatieve frequentie

$\sum_{i=1}^{m} \quad$ betekent dat sommatie plaatsvindt over alle klassen 1 tot en met $m$

\section{Toepassing:}

Het gemiddelde wordt gebruikt om het zwaartepunt van een verdeling te beschrijven. Het vereiste meetniveau is interval. Ze wordt met name toegepast bij het beschrijven van kenmerken die een zogeheten normaalverdeling hebben, dat wil zeggen dat ze ongeveer de volgende vorm hebben:

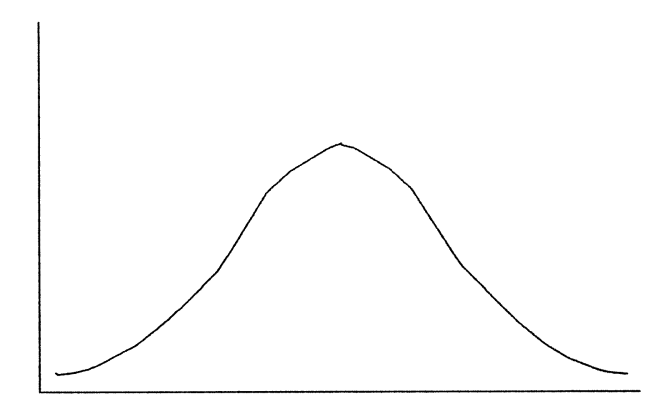

Voorbeeld:

Stel we hebben de volgende verdeling van leeftijdsklassen.

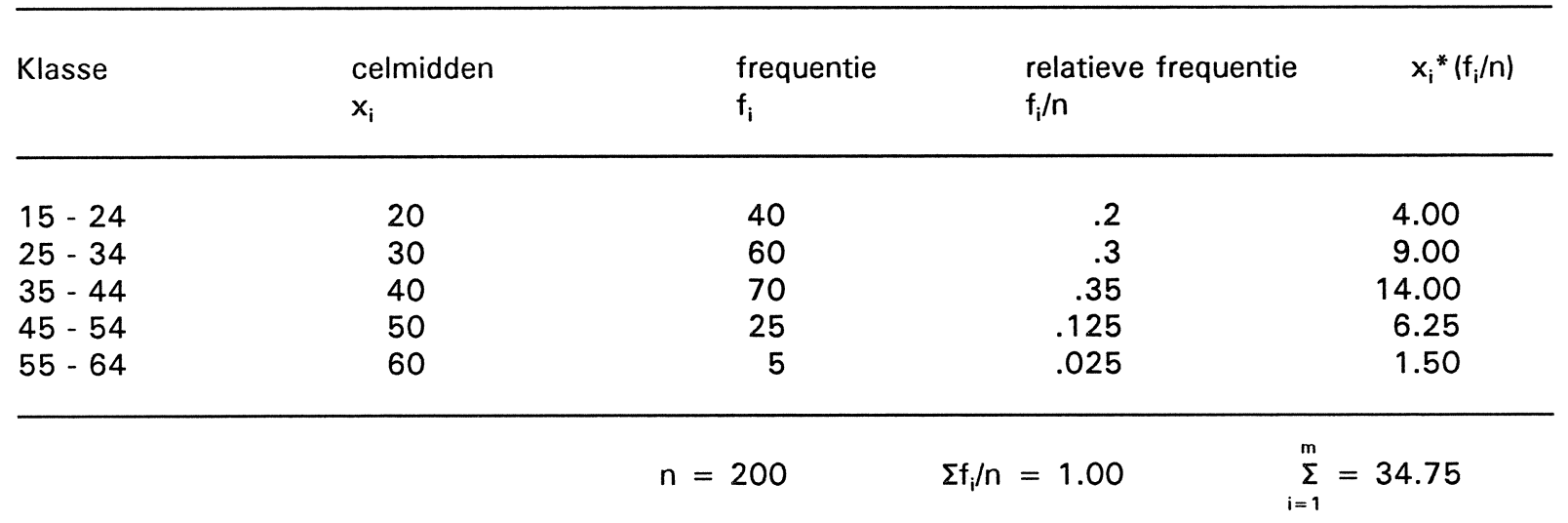

De gemiddelde leeftijd is dan 34.75 jaar. Een vergelijkbare ${ }^{1}$ berekening is uitgevoerd voor een aantal ministeries. Daaruit blijkt dat de gemiddelde leeftijd in 1993 bij Binnenlandse Zaken 38.6 jaar bedroeg, bij WVC 39.9 jaar, bij Economische Zaken 40.2 jaar en bij VROM 41.1 jaar.

\subsubsection{Mediaan}

Definitie:

De mediaan is gelijk aan de waarde van de middelste waarneming wanneer alle waarnemingen geordend zijn van laag naar hoog. Met andere woorden, het is die waarde waar $50 \%$ van de waarnemingen beneden valt.

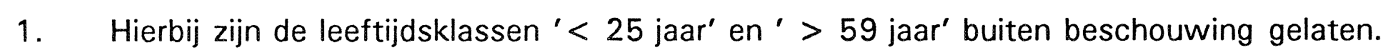


Evenals bij het gemiddelde is bij de berekening van de mediaan vaak sprake van een groot aantal waarnemingen of heeft men alleen de beschikking over gegroepeerde gegevens. In dat geval kan men de mediaan over de gegroepeerde gegevens berekenen. Men bepaalt daartoe eerst in welke klasse i de mediaan valt. Dit kan eenvoudig bepaald worden door de cumulatieve percentages te berekenen en dan vast te stellen in welke klasse i de mediaan valt. De formule voor de berekening van de mediaan wordt dan:

$L_{r}-\left(\frac{F_{i}-\frac{n}{2}}{f_{i}}\right)\left(L_{r}-L_{l}\right)$

waarbij:

$L_{r}=$ de rechter klassegrens

$L_{1}=$ de linker klassegrens

$F_{i}=$ cumulatieve frequentie van 1 tot en met $i$

$f_{i}=$ frequentie in klasse $i$

$\mathrm{n}=$ het aantal waarnemingen

\section{Toepassing:}

De mediaan wordt net als het gemiddelde gebruikt om het zwaartepunt van een verdeling te beschrijven. Het vereiste meetniveau is interval. Ze wordt met name toegepast bij het beschrijven van kenmerken die een scheve verdeling hebben, dat wil zeggen dat ze ongeveer de volgende vorm hebben:
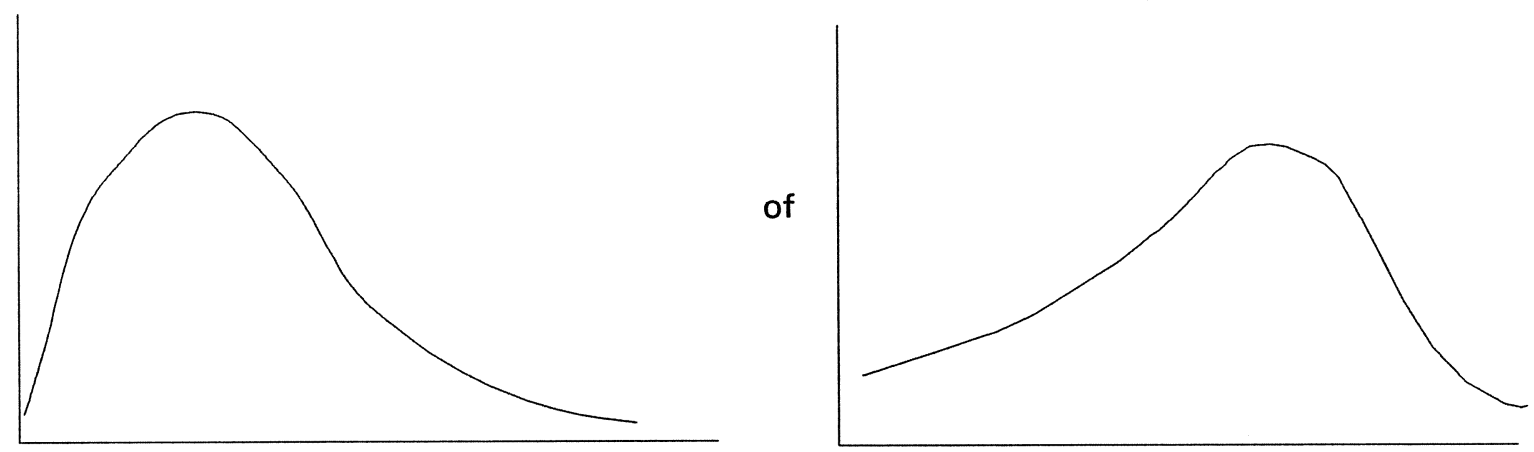

Voorbeeld:

Stel we hebben de volgende verdeling van leeftijdsklassen.

$\begin{array}{llll} & \text { frequentie } & \text { cumulatieve frequentie } & \text { rel. cum. freq. } \\ & f_{i} & F_{i} & F_{i} / n\end{array}$

\begin{tabular}{llll}
$15-24$ & 30 & 30 & .15 \\
$25-34$ & 55 & 85 & .425 \\
$35-44$ & 90 & 175 & .875 \\
$45-54$ & 20 & 195 & .975 \\
$55-64$ & 5 & 200 & 1.0 \\
\hline
\end{tabular}


Uit de laatste kolom kan worden opgemaakt dat de mediaan valt in de klasse van 35 tot en met 44 jaar $^{2}$. De mediaan is dan gelijk aan: $45-((175-200 / 2) / 90) *(45-35)=36.67$ jaar

\subsection{De spreiding van een verdeling}

\subsubsection{Standaardafwijking}

Definitie:

De standaardafwijking is gelijk aan de wortel van het gemiddelde van de gekwadrateerde afwijkingen rond het gemiddelde.

In formule:

$s=\sqrt{\frac{1}{n-1} \sum_{i=1}^{n}\left(x_{i}-\bar{X}\right)^{2}}$

waarbij:

$\mathbf{s}=$ standaardafwijking

$\bar{X}=$ het gemiddelde van kenmerk $X$

$x_{i}=$ de waarde van kenmerk $X$ voor waarneming $i$

$\mathrm{n}=$ het aantal waarnemingen

$\sum_{=1}^{n}$ betekent dat sommatie plaatsvindt over alle waarnemingen 1 tot en met $n$ $=$

Wanneer de standaardafwijking berekend moet worden over gegroepeerde gegevens, dan kan de volgende formule gebruikt worden:

$s=\sqrt{\frac{1}{n-1} \sum_{i=1}^{m}\left(x_{i}-X\right)^{2} f_{i}}$

waarbij:

$\mathbf{s}=$ standaardafwijking

$\bar{X}=$ het gemiddelde van kenmerk $X$

$x_{i}=$ de middelste waarde van klasse $i$

$f_{i}=$ de frequentie in klasse $i$

$\mathrm{n}$ = het aantal waarnemingen

$\mathrm{m}=$ het aantal klassen

$\sum_{i=1}^{m}$ betekent dat sommatie plaatsvindt over alle klassen 1 tot en met $m$

\section{Toepassing:}

De standaardafwijking wordt gebruikt om aan te geven hoe groot de spreiding is van de waarnemingen rond het gemiddelde. Het vereiste meetniveau is interval. Wanneer alle waarnemingen gelijk zijn aan het gemiddelde, dan is de standaardafwijking gelijk aan 0 .

2. De linkergrens bij deze klasse begint bij 35.0 jaar. De rechtergrens is niet 44.0 maar 44.999 jaar. Voor het gemak stellen we dit gelijk aan 45. 
Voorbeeld:

Stel we hebben de volgende verdeling van leeftijdsklassen.

\begin{tabular}{llrrr}
\hline Klasse & $\begin{array}{l}\text { celmidden } \\
x_{i}\end{array}$ & \multicolumn{1}{l}{$\begin{array}{l}\text { frequentie } \\
f_{i}\end{array}$} & $\left(x_{i}-\bar{X}\right)^{2}$ & $\left(x_{i}-\bar{X}\right)^{2 *} f_{i}$ \\
\hline $15-24$ & 20 & 40 & 217.56 & 8702.50 \\
$25-34$ & 30 & 60 & 22.56 & 1353.75 \\
$35-44$ & 40 & 70 & 27.56 & 1929.38 \\
$45-54$ & 50 & 25 & 232.56 & 5814.06 \\
$55-64$ & 60 & 5 & 637.56 & 3187.81 \\
\hline & $n=200$ & & $\sum_{i=1}^{m}=20987.50$
\end{tabular}

De standaardafwijking is $\sqrt{ }(1 / 199 * 20987.50)=10.3$ jaar. Een vergelijkbare ${ }^{3}$ berekening is uitgevoerd voor een aantal ministeries. Daaruit blijkt dat het Ministerie van Economische Zaken en het Ministerie van VROM de kleinste spreiding in leeftijd kennen. De standaardafwijking bedraagt er respectievelijk 8.0 en 8.1 jaar. Bij WVC is de standaardafwijking met 8.6 jaar het grootst van de vier onderscheiden ministeries. Bij Binnenlandse Zaken bedraagt de standaardafwijking 8.3 jaar.

\subsubsection{Coëfficiënt van relatieve variatie}

Definitie:

De coëfficiënt van relatieve variatie is gelijk aan de standaardafwijking van een verdeling gedeeld door het gemiddelde van die verdeling.

In formule:

$$
V=\frac{s}{\bar{X}}
$$

waarbij:

$\mathrm{V}=$ coëfficiënt van relatieve variatie

$\mathrm{s}=$ standaardafwijking

$\bar{X}=$ het gemiddelde van kenmerk $X$

Toepassing:

De coëfficiënt van relatieve variatie wordt evenals de standaardafwijking gebruikt om aan te geven hoe groot de spreiding is van de waarnemingen rond het gemiddelde. Het vereiste meetniveau is interval. Omdat gedeeld wordt door het gemiddelde is deze spreidingscoëfficiënt minder gevoelig voor de eenheid waarin het kenmerk gemeten is. Deze indicator wordt daarom met name gebruikt voor het vergelijken van de spreiding van twee of meer verdelingen die in een verschillende eenheid gemeten zijn, bijvoorbeeld leeftijd in jaren en inkomen in guldens. Ook hier geldt dat wanneer alle waarnemingen gelijk zijn aan het gemiddelde, de coëfficiënt gelijk is aan 0 .

3. Hierbij zijn de leeftijdsklassen ' $<25$ jaar' en '> 59 jaar' buiten beschouwing gelaten. 
Voorbeeld:

De coëfficiënt van relatieve variatie die hoort bij de tabel in paragraaf 4.2.1. bedraagt $10.3 / 34.75=0.30$.

\subsubsection{Scheefheid}

Definitie:

De scheefheid is een maat die aangeeft hoe sterk een verdeling a-symmetrisch verdeeld is.

In formule:

Scheefheid $=\frac{\sum_{i=1}^{n}\left[\left(x_{i}-X\right) / s\right]^{3}}{n}$

waarbij:

$\overline{\mathrm{X}}=$ het gemiddelde van kenmerk $\mathrm{X}$

$x_{i}=$ de waarde van kenmerk $X$ voor waarneming $i$

$s=$ de standaardafwijking

$\mathrm{n}=$ het aantal waarnemingen

$\sum_{i=1}^{n}$ betekent dat sommatie plaatsvindt over alle waarnemingen 1 tot en met $n$

De scheefheid kan ook berekend worden voor gegroepeerde gegevens. De formule wordt dan:

Scheefheid $=\frac{\sum_{i=1}^{m} f_{i}\left[\left(x_{i}-X\right) / s\right]^{3}}{n}$

waarbij:

$\bar{X}=$ het gemiddelde van kenmerk $X$

$x_{i}=$ de middelste waarde van klasse $i$

$s=$ de standaardafwijking

$f_{i}=$ de frequentie in klasse $i$

$\mathrm{n}=$ het aantal waarnemingen

$\mathrm{m}=$ het aantal klassen

$\sum_{i=1}^{m}$ betekent dat sommatie plaatsvindt over alle klassen 1 tot en met $m$ $i=1$

Toepassing:

De scheefheid is een maat die aangeeft in hoeverre een bepaald kenmerk scheef verdeeld is, dat wil zeggen ze geeft aan in hoeverre een verdeling afwijkt van een symmetrische vorm. Het vereiste meetniveau is interval. Ze kan met name toegepast worden in die situaties waar men geïnteresseerd is in een evenwichtige verdeling, bijvoorbeeld bij de verdeling naar leeftijd. De scheefheid is 0 , wanneer de verdeling een perfect symmetrische klok-vorm heeft. Ze is positief wanneer de waarnemingen aan de linkerkant van de verdeling zich dicht bij het gemiddelde bevinden, terwijl de waarnemingen aan de rechterkant ver van het gemiddelde liggen. Een negatieve waarde duidt op het omgekeerde: een clustering van waarnemingen direct rechts van het gemiddelde en extreme waarden links van het gemiddelde. 
Voorbeeld:

Stel we hebben de volgende verdeling van leeftijdsklassen.

\begin{tabular}{lcccc}
\hline Klasse & $\begin{array}{l}\text { celmidden } \\
x_{i}\end{array}$ & $\begin{array}{l}\text { frequentie } \\
f_{i}\end{array}$ & {$\left[\left(x_{i}-\bar{X}\right) / s\right]^{3}$} & {$\left[\left(x_{i}-\bar{X}\right) / s\right]^{3 *} f_{i} / n$} \\
\hline $5-24$ & 20 & 40 & -2.9367322 & -0.5873464 \\
$25-34$ & 30 & 60 & -0.0980773 & -0.0294231 \\
$35-44$ & 40 & 70 & 0.1324237 & 0.0463482 \\
$45-54$ & 50 & 5 & 3.2456211 & 0.4057026 \\
$55-64$ & 60 & 5 & 14.732364 & 0.3683091 \\
\hline & & & & $\mathrm{m}$ \\
\hline
\end{tabular}

De scheefheid van deze verdeling bedraagt 0.20 . De positieve waarde duidt er op dat de verdeling niet helemaal symmetrisch is. In de laagste leeftijdsklassen zitten verhoudingsgewijs meer personeelsleden, terwijl er relatief weinig personeelsleden zitten in de hoogste leeftijdscategorieën.

Een vergelijkbare berekening ${ }^{4}$ is gemaakt voor de ontwikkeling van de leeftijdsverdeling van het personeel in dienst van de rijksoverheid (bron: Overheid en Arbeidsmarkt, 1993, p. 36 e.v.).

Jaartal Scheefheid

$\begin{array}{ll}1976 & 0.03 \\ 1979 & 0.17 \\ 1982 & 0.38 \\ 1985 & 1.44 \\ 1988 & 0.45 \\ 1991 & 0.94\end{array}$

Hieruit blijkt dat de verdeling naar leeftijd in de loop der jaren sterk is veranderd. In 1976 was er nog sprake van een perfect symmetrische verdeling. In de jaren daarna is de verdeling steeds schever geworden met een sterke concentratie van het personeel in de jongere leeftijdsklassen. Hoewel 1985 de meest scheve verdeling laat zien, is ook in de jaren daarna sprake van een scheve verdeling.

\subsubsection{Kurtosis}

Definitie:

De kurtosis is een maat die de gepiektheid of platheid van een curve weergeeft.

4. Hierbij zijn de leeftijdsklassen ' $<25$ jaar' en '> 59 jaar' buiten beschouwing gelaten. 
In formule:

Kurtosis $=\frac{\sum_{i=1}^{n}\left[\left(x_{i}-X\right) / s\right]^{4}}{n}-3$

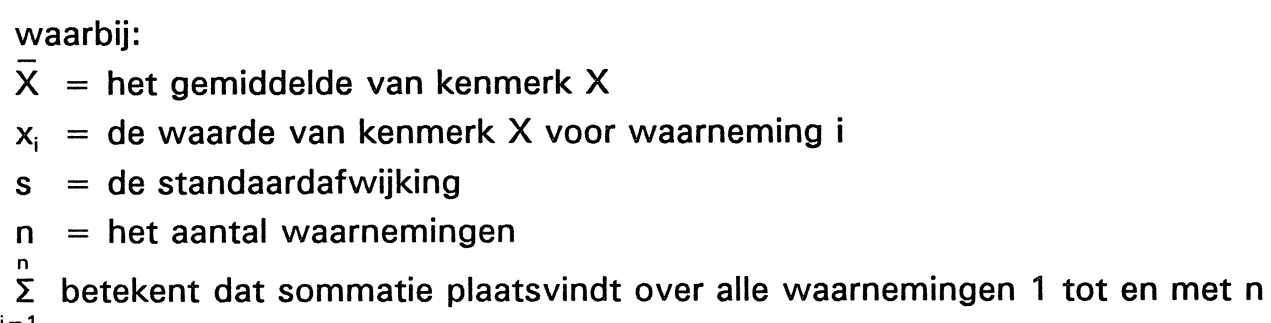

De kurtosis kan ook berekend worden voor gegroepeerde gegevens. De formule wordt dan:

Kurtosis $=\frac{\sum_{i=1}^{m} f_{i}\left[\left(x_{i}-X\right) / s\right]^{4}}{n}-3$

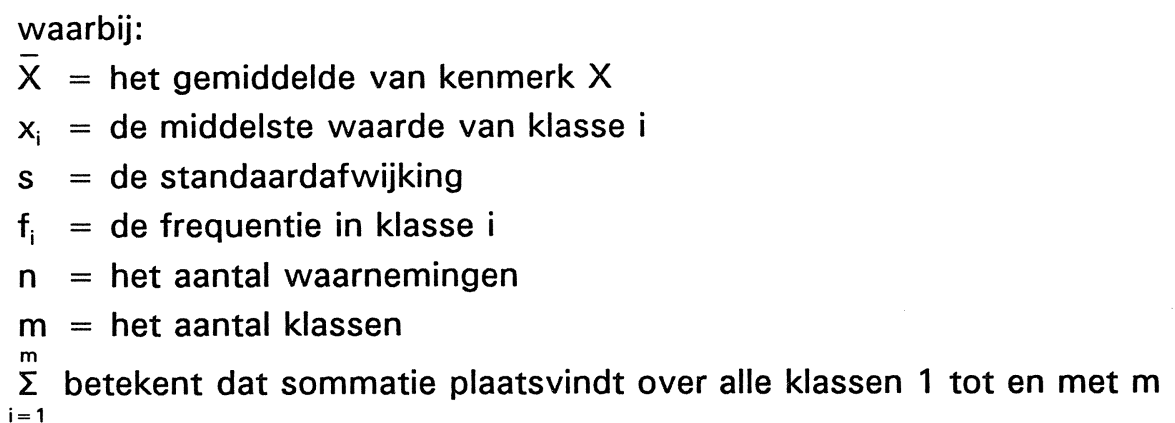

De kurtosis is een maat die aangeeft of een bepaald kenmerk een langgerekte platte verdeling heeft of dat ze juist een smalle gepiekte verdeling heeft. Het vereiste meetniveau is interval. Ze kan met name toegepast worden in die situaties waar men geïnteresseerd is in de vraag of een bepaald kenmerk gelijkmatig verdeeld is over de verschillende klassen of dat ze juist in een klasse geconcentreerd is. De kurtosis is 0 wanneer het een zogeheten normaalverdeling ${ }^{5}$ betreft. Ze is positief wanneer de verdeling meer gepiekt is (c.q. smaller) is dan een normaalverdeling. Ze is negatief wanneer de verdeling platter (c.q. langgerekter) is dan bij een normaalverdeling.

5. Voor een afbeelding van een normaalverdeling, zie paragraaf 4.1.1. 
Voorbeeld:

Stel we hebben de volgende verdeling van leeftijdsklassen.

\begin{tabular}{lcccc}
\hline Klasse & $\begin{array}{l}\text { celmidden } \\
x_{i}\end{array}$ & $\begin{array}{l}\text { frequentie } \\
f_{i}\end{array}$ & {$\left[\left(x_{i}-\bar{X}\right) / s\right]^{4}$} & {$\left[\left(x_{i}-\bar{X}\right) / s\right]^{4 *} f_{i} / n$} \\
\hline $5-24$ & 20 & 40 & 4.2055144 & \\
$25-34$ & 30 & 60 & 0.0452298 & 0.8411028 \\
$35-44$ & 40 & 70 & 0.0674975 & 0.0135689 \\
$45-54$ & 50 & 25 & 4.8054098 & 0.6006762 \\
$55-64$ & 60 & 5 & 36.115746 & 0.9028936 \\
& & & & \\
\hline
\end{tabular}

$$
n=200
$$

De kurtosis van deze verdeling bedraagt $(2.38-3)=-0.62$. De negatieve waarde duidt er op dat de verdeling platter is dan het geval zou zijn bij een normaalverdeling.

Ook hier is een vergelijkbare ${ }^{6}$ berekening uitgevoerd voor de ontwikkeling van de leeftijdsverdeling van het personeel in dienst van de rijksoverheid.

Jaartal Kurtosis

\begin{tabular}{lr}
1976 & -1.39 \\
1979 & -1.35 \\
1982 & -1.16 \\
1985 & 0.07 \\
1988 & -0.81 \\
1991 & -0.58 \\
\hline
\end{tabular}

Voor de meeste jaren geldt dat de verdeling over de leeftijdsklassen platter is dan het geval zou zijn bij een normaalverdeling. Dat betekent dat er sprake is van een vrij gelijkmatige verdeling over de verschillende leeftijdsklassen. Wel kan men constateren dat in de loop der jaren de gepiektheid van de leeftijdsverdeling toeneemt. Dit betekent dat de concentratie van personeel in de extreme leeftijdscategorie afneemt ten gunste van de middelste categorieën. Het jaar 1985 doorbreekt als het ware deze ontwikkeling met een kurtosis die vergelijkbaar is met die van een normaalverdeling.

\subsubsection{Gini-Hirschmann coëfficiënt}

Definitie:

De Gini-Hirschmann coëfficiënt is een maatstaf die de spreiding van een kenmerk aangeeft over de onderliggende klassen

6. Hierbij zijn de leeftijdsklassen ' $<25$ jaar' en '> 59 jaar' buiten beschouwing gelaten. 
In formule:

$$
G H=\left(1-\sum_{i=1}^{m}\left(\frac{f_{i}}{n}\right)^{2}\right) * \frac{m}{m-1}
$$

waarbij:

$f_{i}=$ de frequentie in klasse $i$

$\mathrm{n}=$ het aantal waarnemingen

$\mathrm{m}=$ het aantal klassen

$\sum^{m}$ betekent dat sommatie plaatsvindt over alle klassen 1 tot en met $m$ $i=1$

\section{Toepassing:}

De Gini-Hirschmann coëfficiënt is een maatstaf die gebruikt wordt om de spreiding van een kenmerk aan te geven over de onderliggende klassen. Ze kan in tegenstelling tot de eerder besproken spreidingsmaatstaven ook gebruikt worden voor kenmerken van nominaal of ordinaal meetniveau. Ze neemt de waarde 0 aan wanneer alle waarnemingen in slechts één categorie vallen en er dus geen sprake is van spreiding. Ze neemt de waarde 1 aan wanneer de waarnememingen gelijkmatig gespreid zijn over alle categorieën.

Voorbeeld:

Stel we hebben de volgende verdeling van vacatures naar functierichting.

\begin{tabular}{|c|c|c|c|}
\hline Richting & 1989 & 1990 & 1991 \\
\hline Wis-, Natuur- en Scheikunde & 275 & 414 & 382 \\
\hline Secretariaat en Administratie & 262 & 408 & 294 \\
\hline Administratief Beheer & 479 & 416 & 249 \\
\hline Gezondheidszorg & 137 & 220 & 203 \\
\hline Openbaar Bestuur & 638 & 418 & 173 \\
\hline Juridische, Economische, Politieke Wetenschappen & 105 & 192 & 141 \\
\hline Informatieverwerking & 209 & 218 & 138 \\
\hline Landbouw & 35 & 205 & 95 \\
\hline Bedrijfsbeheer, Organisatie en Management & 75 & 129 & 83 \\
\hline Sociale en Menswetenschappen & 66 & 65 & 63 \\
\hline Humaniora en Theologie & 27 & 36 & 48 \\
\hline Personeelswerk & 83 & 103 & 44 \\
\hline Voorlichting & 48 & 63 & 36 \\
\hline Werktuig-, scheeps-, en vliegtuigbouw & 30 & 28 & 28 \\
\hline Bouwkunde & 53 & 45 & 27 \\
\hline Maatschappelijke Zorg & 86 & 61 & 22 \\
\hline
\end{tabular}

(Bron: Overheid en Arbeidsmarkt 1992, p.175)

$n=2608 \quad n=3021 \quad n=2026$




\begin{tabular}{|c|c|c|c|}
\hline Richting & \multicolumn{3}{|c|}{$\left(f_{i} / n\right)^{2}$} \\
\hline Wis-, Natuur- en Scheikunde & 0.01112 & 0.01878 & 0.03555 \\
\hline Secretariaat en Administratie & 0.01009 & 0.01824 & 0.02106 \\
\hline Administratief Beheer & 0.03373 & 0.01896 & 0.01510 \\
\hline Gezondheidszorg & 0.00276 & 0.00530 & 0.01004 \\
\hline Openbaar Bestuur & 0.05984 & 0.01914 & 0.00729 \\
\hline Juridische, Economische, Politieke Wetens. & 0.00162 & 0.00404 & 0.00484 \\
\hline Informatieverwerking & 0.00642 & 0.00521 & 0.00464 \\
\hline Landbouw & 0.00018 & 0.00460 & 0.00220 \\
\hline Bedrijfsbeheer, Organisatie en Management & 0.00083 & 0.00182 & 0.00168 \\
\hline Sociale en Menswetenschappen & 0.00064 & 0.00046 & 0.00097 \\
\hline Humaniora en Theologie & 0.00011 & 0.00014 & 0.00056 \\
\hline Personeelswerk & 0.00101 & 0.00116 & 0.00047 \\
\hline Voorlichting & 0.00034 & 0.00043 & 0.00032 \\
\hline Werktuig-, scheeps-, en vliegtuigbouw & 0.00013 & 0.00009 & 0.00019 \\
\hline Bouwkunde & 0.00041 & 0.00022 & 0.00018 \\
\hline Maatschappelijke Zorg & 0.00108 & 0.00041 & 0.00012 \\
\hline & .13031 & 0.09900 & 0.10521 \\
\hline
\end{tabular}

De Gini-Hirschmann coëfficiënt bedroeg in 1989 0.93, in 19900.96 en in 1991 0.95. Dat betekent dat in zijn algemeenheid de vacatures vrij gelijkmatig verdeeld zijn over de onderscheiden richtingen. In vergelijking met 1990 was er in 1989 wel een iets sterkere concentratie van vacatures in bepaalde functierichtingen.

\subsection{Ontwikkelingen in de tijd}

\subsubsection{Groeivoet}

Definitie:

De groeivoet geeft de procentuele toe- of afname van een kenmerk tussen twee tijdstippen.

In formule:

Groeivoet $=\frac{x_{t=i}}{x_{t=i-1}} * 100 \%$

waarbij:

$\mathrm{x}_{\mathrm{t}=\mathrm{i}} \quad=$ waarde van kenmerk $\mathrm{x}$ op tijdstip $\mathrm{i}$

$x_{t=i-1}=$ waarde van kenmerk $x$ op tijdstip $\mathrm{i}-1$

\section{Toepassing:}

De groeivoet wordt gebruikt om op een overzichtelijke wijze de ontwikkelingen in de groei van een kenmerk in de tijd te volgen. Het vereiste meetniveau is interval. 
Voorbeeld:

Het personeel in dienst van het Rijk is sinds 1976 als volgt gegroeid.

\begin{tabular}{|c|c|c|c|c|}
\hline Jaar & absoluut & groeivoet & $\left|G V_{t=i}-100\right|^{*}$ & $\left|G V_{t=i+1}-G V_{t=i}\right|^{* *}$ \\
\hline 1976 & 135120 & & & \\
\hline 1977 & 137909 & 102.1 & 2.1 & 0.3 \\
\hline 1978 & 141170 & 102.4 & 2.4 & 0.2 \\
\hline 1979 & 144227 & 102.2 & 2.2 & 0.6 \\
\hline 1980 & 146483 & 101.6 & 1.6 & 1.5 \\
\hline 1981 & 151095 & 103.1 & 3.1 & 0.7 \\
\hline 1982 & 154723 & 102.4 & 2.4 & 0.8 \\
\hline 1983 & 157200 & 101.6 & 1.6 & 4.1 \\
\hline 1984 & 153260 & 97.5 & 2.5 & 3.2 \\
\hline 1985 & 154400 & 100.7 & 0.7 & 2.3 \\
\hline 1986 & 159000 & 103.0 & 3.0 & 4.5 \\
\hline 1987 & 156598 & 98.5 & 1.5 & 1.8 \\
\hline 1988 & 151447 & 96.7 & 3.3 & 1.6 \\
\hline 1989 & 148843 & 98.3 & 1.7 & 0.3 \\
\hline 1990 & 146709 & 98.6 & 1.4 & 1.3 \\
\hline 1991 & 142743 & 97.3 & 2.7 & \\
\hline \multicolumn{5}{|c|}{ zie (4.3.2) } \\
\hline ** & \multicolumn{4}{|c|}{ zie (4.3.3) } \\
\hline
\end{tabular}

Uit de groeivoeten is te zien dat tot 1983 de omvang van het personeel in rijksdienst jaarlijks met zo'n $2 \%$ toenam. Vanaf 1986 is er sprake van een constante daling van de werkgelegenheid met zo'n 1.5 tot $3 \%$ per jaar.

\subsubsection{Fluctuatie-index}

Definitie:

De fluctuatie-index geeft aan hoe instabiel een kenmerk is.

In formule:

Stabiliteit $=\sum_{i=1}^{m} \frac{\left|G V_{t=i}-100\right|}{m}$

waarbij:

$\mathrm{GV}_{\mathrm{t}=\mathrm{i}} \quad=$ groeivoet op tijdstip $\mathrm{i}$

$\mathrm{m}_{\mathrm{m}} \quad=$ aantal tijdstippen

$\sum^{m} \quad$ betekent dat de sommatie plaatsvindt over de tijdstippen 1 tot en met $\mathrm{m}$

Toepassing:

De fluctuatie-index geeft op eenvoudige wijze aan hoe sterk een kenmerk fluctueert in de tijd. Het vereiste meetniveau is interval. Ze bedraagt 0 wanneer het kenmerk op elk tijdstip dezelfde omvang heeft. Naarmate ze van jaar op jaar sterker fluctueert heeft de index een hogere waarde. 
Voorbeeld:

In het hierboven beschreven voorbeeld van de ontwikkeling van het personeelsbestand van de rijksoverheid bedraagt de fluctuatie 2.01. Dit wil zeggen dat gemiddeld genomen de werkgelegenheid bij de rijksoverheid van jaar op jaar met zo'n $2 \%$ fluctueert.

\subsubsection{Ontwikkelingsindex}

Definitie:

De ontwikkelingsindex geeft aan hoe (in)stabiel een kenmerk zich ontwikkelt.

In formule:

Ontwikkelingsindex $=\sum_{i=1}^{m} \frac{\left|G V_{t=i+1}-G V_{t=i}\right|}{m}$

waarbij:

$\mathrm{GV}_{\mathrm{t}=\mathrm{i}} \quad=$ groeivoet op tijdstip $\mathrm{i}$

$\mathrm{GV}_{\mathrm{t}=\mathrm{i}+1}=$ groeivoet op tijdstip $\mathrm{i}+1$

$\mathrm{m} \quad=$ aantal tijdstippen

$\sum_{i=1}^{m} \quad$ betekent dat de sommatie plaatsvindt over de tijdstippen 1 tot en met $m$

$\sum_{i=1}$

Toepassing:

De index geeft aan of de ontwikkeling in een kenmerk stabiel is, dat wil zeggen of er sprake is van een constante groei, gelijkblijven of daling, of dat er juist sprake is van veelvuldige afwisseling van groei en krimp. Het vereiste meetniveau is interval. Zij is 0 wanneer er sprake is van een stabiele ontwikkeling. Naarmate er meer afwisseling is tussen groei en krimp, of de mate waarin groei of krimp plaats vindt, heeft de index een hogere waarde.

Voorbeeld:

In het hierboven beschreven voorbeeld van de ontwikkeling van het personeelsbestand van de rijksoverheid bedraagt de ontwikkelingsindex 1.45 . 


\section{ANALYSES}

Bij de voorgaande maten was uitsluitend sprake van reductie van informatie: op welke wijze kan een grote hoeveelheid informatie op gecomprimeerde wijze worden gepresenteerd? Bij de technieken die in dit hoofdstuk worden gepresenteerd is niet alleen sprake van datareductie, maar wordt tevens getracht om de gegevens in een bepaald perspectief te zetten. Eerst wordt een tweetal maten gepresenteerd waarmee kan worden aangegeven in hoeverre twee verdelingen op elkaar lijken of juist van elkaar afwijken. Vervolgens wordt een maat gepresenteerd waarmee kan worden vastgesteld of de ontwikkelingen in twee verdelingen van elkaar afwijken. Tenslotte wordt een techniek gepresenteerd om de ontwikkeling in een bepaald kenmerk uiteen te leggen in de effecten van verschillende onderliggende factoren.

\subsection{Gelijkheid}

\section{Definitie:}

De gelijkheidsmaatstaf geeft de samenhang aan tussen twee verdelingen.

In formule:

$$
r_{a, b}=\frac{\sum_{i=1}^{m} p_{a, i} * p_{b, i}}{\sqrt{\sum_{i=1}^{m} p_{a, i}^{2} \sum_{i=1}^{m} p_{b, i}^{2}}}
$$

waarbij:

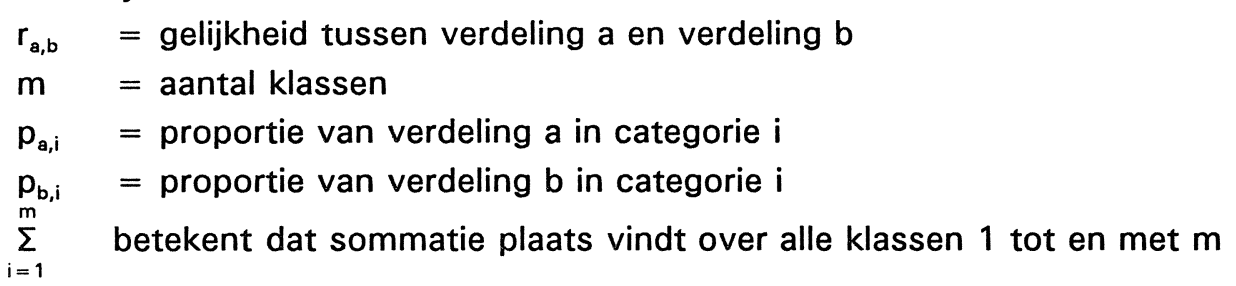

\section{Toepassing:}

De gelijkheidsmaatstaf wordt toegepast om de samenhang of gelijkheid tussen twee verdelingen vast te stellen. Er worden geen eisen gesteld aan het meetniveau. Ze is gelijk aan 1 wanneer beide verdelingen precies gelijk zijn. Ze bedraagt 0 wanneer er geen enkele categorie is waar beide verdelingen in vertegenwoordigd zijn. ${ }^{7}$

7. De gelijkheidsmaatstaf kan op elke verdeling worden toegepast en stelt geen eisen aan het meetniveau van het kenmerk. Ze is nauw verwant aan een correlatie voor kenmerken op intervalniveau. 
Voorbeeld:

Stel we hebben de volgende verdeling van personen over opleidingsachtergrond per ministerie.

\begin{tabular}{lrrrrr}
\hline & Landbouw & O\&W & $p_{a, i}^{*} p_{b, i}$ & $p_{a, i}^{2}$ & $p_{b, 1}^{2}$ \\
\hline Basisschool & $5 \%$ & $10 \%$ & 0.005 & 0.0025 & 0.01 \\
LBO/MAVO & $15 \%$ & $20 \%$ & 0.03 & 0.0225 & 0.04 \\
MBO/HAVO/NWO & $30 \%$ & $40 \%$ & 0.12 & 0.09 & 0.16 \\
HBO & $30 \%$ & $20 \%$ & 0.06 & 0.09 & 0.04 \\
WO & $20 \%$ & $10 \%$ & 0.02 & 0.04 & 0.01 \\
\hline & $100 \%$ & $100 \%$ & $\sum_{i=1}^{m}=0.235$ & $\sum_{i=1}^{m}=0.245$ & $\sum_{i=1}^{m}=0.26$
\end{tabular}

De gelijkheid in de verdeling naar opleiding tussen beide ministeries bedraagt dan $(0.235) / \sqrt{\left(0.245^{*} 0.26\right)}=0.93$.

\subsection{Segregatie-index}

Definitie:

De segregatie-index geeft aan hoeveel procent verandering moet plaatsvinden in een verdeling bij een bepaalde groep om een zelfde verdeling te bewerkstelligen als bij een andere groep.

In formule:

$s_{a, b}=1 / 2 \sum_{i=1}^{m}\left|\frac{f_{a, i}}{n_{a}} * 100 \%-\frac{f_{b, i}}{n_{b}} * 100 \%\right|$

waarbij:

$\mathrm{s}_{\mathrm{a}, \mathrm{b}} \quad=$ segregatie tussen verdeling a en verdeling $\mathrm{b}$

$f_{a, i} \quad=$ frequentie van verdeling $a$ in klasse $i$

$f_{b, i} \quad=$ frequentie van verdeling $b$ in klasse $i$

$\mathrm{n}_{\mathrm{a}} \quad=$ aantal waarnemingen in verdeling a

$\mathrm{n}_{\mathrm{b}} \quad=$ aantal waarnemingen in verdeling $\mathrm{b}$

$\mathrm{m} \quad=$ aantal klassen

$\sum_{i=1}^{m}$ betekent dat sommatie plaats vindt over alle klassen 1 tot en met $m$

\section{Toepassing:}

De segregatie-index wordt gebruikt om aan te geven in hoeverre twee verdelingen van elkaar afwijken. Net als bij de gelijkheidsmaatstaf worden geen eisen gesteld aan het meetniveau. De segregatie tussen twee groepen $a$ en $b$ bedraagt $0 \%$ wanneer de verdelingen van $a$ en $b$ over het betreffende kenmerk identiek zijn. Ze bedraagt $100 \%$ wanneer alle waarnemingen in groep a (resp. groep b) van categorie zou moeten veranderen om eenzelfde verdeling te bewerkstelligen als in groep b (resp. groep a).

Voorbeeld:

Aan het jaarboek Overheid en Arbeidsmarkt ontlenen we de volgende verdeling van mannen en vrouwen over de verschillende BBRA-niveaus. 


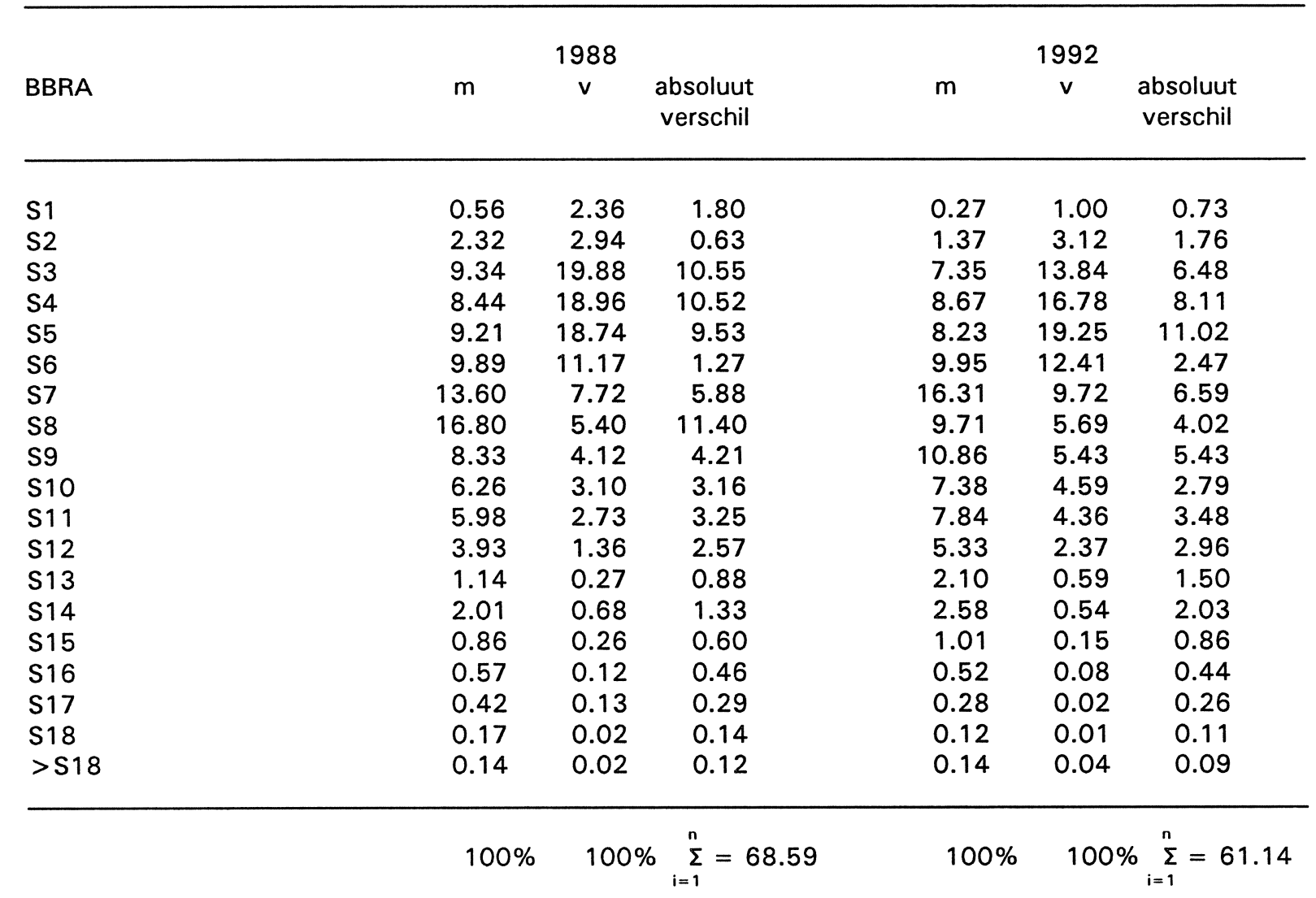

In 1988 bedroeg de segregatie in de verdeling over BBRA-niveaus tussen mannen en vrouwen $(1 / 2 * 68.6 \%=) 34 \%$. Dat wil zeggen dat $34 \%$ van de vrouwen (of $34 \%$ van de mannen) een andere BBRA-schaal zou moeten hebben om een exact gelijke verdeling tussen mannen en vrouwen te creëren. In 1992 is deze segregatie tussen mannen en vrouwen afgenomen tot $31 \%$.

\subsection{Afwijkingsindex}

Definitie:

De afwijkingsindex geeft aan in hoeverre de ontwikkeling in een kenmerk bij de ene groep afwijkt van de ontwikkeling bij een andere groep.

In formule:

$A_{a, b}=\sum_{i=1}^{m} \frac{\left|G V_{a, t=i}-G V_{b, t=i}\right|}{m}$

waarbij:

$\mathrm{A}_{\mathrm{a}, \mathrm{b}} \quad=$ afwijking in ontwikkeling tussen groep $\mathrm{a}$ en $\mathrm{b}$

$\mathrm{GV}_{\mathrm{a}, \mathrm{t}=\mathrm{i}}=$ groeivoet op tijdstip i bij groep a

$\mathrm{GV}_{\mathrm{b}, \mathrm{t}=\mathrm{i}}=$ groeivoet op tijdstip $\mathrm{i}$ bij groep $\mathrm{b}$

$\mathrm{m} \quad=$ aantal tijdstippen

$\sum_{i=1}^{m} \quad$ betekent dat sommatie plaats vindt over de tijdstippen 1 tot en met $m$ 
Toepassing:

De afwijkingsindex wordt gebruikt om aan te geven of twee groepen eenzelfde ontwikkeling hebben gekend in een bepaald kenmerk. Het vereiste meetniveau is interval. De afwijking bedraagt 0 wanneer de groeivoeten op de opeenvolgende tijdstippen voortdurend aan elkaar gelijk zijn geweest.

\section{Voorbeeld:}

In paragraaf 4.3.1. is de ontwikkeling in de werkgelegenheid van het rijksoverheidspersoneel geschetst. Voor gemeenten en provincies kunnen vergelijkbare cijfers worden gepresenteerd.

\begin{tabular}{|c|c|c|c|c|c|c|}
\hline Jaar & $\begin{array}{c}\text { groeivoet } \\
\text { Rijk }\end{array}$ & $\begin{array}{l}\text { groeivoet } \\
\text { provincie }\end{array}$ & $\begin{array}{l}\text { absolute } \\
\text { verschil }\end{array}$ & $\begin{array}{c}\text { groeivoet } \\
\text { Rijk }\end{array}$ & $\begin{array}{l}\text { groeivoet } \\
\text { gemeente }\end{array}$ & $\begin{array}{l}\text { absolute } \\
\text { verschil }\end{array}$ \\
\hline 1977 & 102.1 & & & 102.1 & 101.8 & 0.2 \\
\hline 1978 & 102.4 & & & 102.4 & 117.3 & 15.0 \\
\hline 1979 & 102.2 & 101.5 & 0.7 & 102.2 & 101.0 & 1.1 \\
\hline 1980 & 101.6 & 109.7 & 8.2 & 101.6 & 103.4 & 1.8 \\
\hline 1981 & 103.1 & 98.3 & 4.8 & 103.1 & 103.3 & 0.1 \\
\hline 1982 & 102.4 & 103.4 & 1.0 & 102.4 & 101.6 & 0.8 \\
\hline 1983 & 101.6 & 101.2 & 0.4 & 101.6 & 99.6 & 2.0 \\
\hline 1984 & 97.5 & 102.2 & 4.7 & 97.5 & 99.4 & 1.9 \\
\hline 1985 & 100.7 & 102.7 & 2.0 & 100.7 & 98.0 & 2.7 \\
\hline 1986 & 103.0 & 100.8 & 2.1 & 103.0 & 100.7 & 2.3 \\
\hline 1987 & 98.5 & 100.4 & 1.9 & 98.5 & 97.6 & 0.9 \\
\hline 1988 & 96.7 & 96.4 & 0.3 & 96.7 & 97.1 & 0.4 \\
\hline 1989 & 98.3 & 99.1 & 0.8 & 98.3 & 97.4 & 0.9 \\
\hline 1990 & 98.6 & 91.8 & 6.8 & 98.6 & 98.9 & 0.4 \\
\hline 1991 & 97.3 & 85.6 & 11.7 & 97.3 & 99.2 & 1.9 \\
\hline
\end{tabular}

De afwijking van de ontwikkeling bij de gemeentes ten opzichte van de rijksoverheid bedraagt 2.2. Bij provincies bedraagt deze afwijking 3.5. Dat betekent dat de ontwikkeling van de werkgelegenheid bij gemeentes gemiddeld genomen zo'n $2 \%$ afwijkt van die bij de rijksoverheid. Bij provincies is deze afwijking gemiddeld anderhalf keer zo hoog.

\subsection{Shift-share analyse}

Definitie:

Een shift-share analyse legt de ontwikkeling in een bepaald kenmerk uiteen in een algemene ontwikkeling van dat kenmerk in elk van de subpopulaties (shift), veranderingen in de aandelen van subpopulaties (share) en een rest-categorie (interactie-effect), waarmee ongelijke ontwikkelingen in het kenmerk bij subpopulaties worden gevangen.

Toepassing:

Shift-share analyse is een methode om de ontwikkeling in een bepaald kenmerk nader te analyseren. Er worden geen eisen gesteld aan het meetniveau. De toepassing laat zich het best illustreren aan de hand van een voorbeeld. Stel we zijn geïnteresseerd in de ontwikkeling van het aantal deeltijders. Nu kan het zijn dat het aantal deeltijders is toegenomen, omdat zowel 
mannen als vrouwen meer in deeltijd zijn gaan werken (shift), of omdat er relatief meer vrouwen zijn gaan werken die altijd al meer in deeltijd werkzaam waren (share). Shift-share analyse legt het effect van beide ontwikkelingen uiteen door na te gaan wat er gebeurt met het aantal deeltijdwerkers, wanneer alleen maar het aandeel van vrouwen toeneemt bij constant blijven van het percentage deeltijdwerkers per geslacht, en wat er zou gebeuren met het aantal deeltijdwerkers bij het stijgen van het percentage deeltijdwerkers onder constant blijven van de verdeling naar geslacht ${ }^{8}$.

In formule:

Het totaal effect bij de shift-share analyse ziet er als volgt uit:

$W P d t_{t} / W P_{t}-W P d t_{t-1} / W P_{t-1}$

waarbij:

$W \mathrm{Wdt}_{\mathrm{t}}=$ het aantal deeltijdwerkers op tijdstip $\mathrm{t}$

$\mathrm{WP}_{\mathrm{t}} \quad=$ het aantal werkzame personen op tijdstip $\mathrm{t}$

$\mathrm{WPdt}_{\mathrm{t}-1}=$ het aantal deeltijdwerkers op tijdstip $\mathrm{t}-1$

$\mathrm{WP}_{\mathrm{t}-1}=$ het aantal werkzame personen op tijdstip $\mathrm{t}-1$

Het geslachts-effect is dan als volgt:

$\left(d_{m, t-1}\left(g_{m, t}-g_{m, t-1}\right)\right)+\left(d_{v, t-1}\left(g_{v, t}-g_{v, t-1}\right)\right)$

waarbij:

$d_{m, t-1}=$ percentage deeltijdwerkers onder mannen op tijdstip $t-1$

$d_{v, t-1}=$ percentage deeltijdwerkers onder vrouwen op tijdstip t-1

$\mathrm{g}_{\mathrm{m}, \mathrm{t}} \quad=$ percentage mannen op tijdstip $\mathrm{t}$

$\mathrm{g}_{\mathrm{m}, \mathrm{t}-1} \quad=$ percentage mannen op tijdstip $\mathrm{t}-1$

$\mathrm{g}_{\mathrm{v}, \mathrm{t}} \quad=$ percentage vrouwen op tijdstip $\mathrm{t}$

$\mathrm{g}_{\mathrm{v}, \mathrm{t}-1} \quad=$ percentage vrouwen op tijdstip $\mathrm{t}-1$

Het deeltijd-effect is:

$\left(g_{m, t-1}\left(d_{m, t}-d_{m, t-1}\right)\right)+\left(g_{v, t-1}\left(d_{v, t}-d_{v, t-1}\right)\right)$

waarbij:

$d_{m, t} \quad=$ percentage deeltijdwerkers onder mannen op tijdstip $t$

$d_{v, t} \quad=$ percentage deeltijdwerkers onder vrouwen op tijdstip $t$

Het interactie-effect ziet er als volgt uit:

$\left(\left(g_{m, t}-g_{m, t-1}\right) *\left(d_{m, t}-d_{m, t-1}\right)\right)+\left(\left(g_{v, t}-g_{v, t-1}\right) *\left(d_{v, t}-d_{v, t-1}\right)\right)$

Uit het jaarboek ontlenen we de volgende cijfers over de ontwikkeling van het aantal deeltijders.

8. In dit voorbeeld wordt de Shift-Share analyse toegepast op twee dimensies (aantal deeltijdwerkers en aantal vrouwen). In beginsel zou men in de Shift-Share analyse ook meerdere dimensies kunnen betrekken. Omdat de uitkomsten daarvan door het interactie-effect steeds moeilijker te interpreteren zijn, zou de voorkeur gegeven moeten worden aan een groeimodel gebaseerd op tijdreeksen (multiple regressie). Hiervoor kan het best gebruik worden gemaakt van bestaande software paketten, zoals SPPS. 


\begin{tabular}{|c|c|c|c|c|c|c|c|c|c|}
\hline Jaar & totaal & $\begin{array}{l}\% d \\
\operatorname{man}\end{array}$ & $\begin{array}{l}\text { eltijd } \\
\text { vrouw }\end{array}$ & $\begin{array}{c}\% \text { werkzan } \\
\text { man }\end{array}$ & $\begin{array}{l}\text { he personen } \\
\text { vrouw }\end{array}$ & $\begin{array}{l}\text { effecten } \\
\text { totaal }\end{array}$ & structuur & deeltijd & interactie \\
\hline $\begin{array}{l}1976 \\
1992\end{array}$ & $\begin{array}{r}4.48 \\
16.33\end{array}$ & $\begin{array}{l}0.95 \\
4.89\end{array}$ & $\begin{array}{r}19.99 \\
45.05\end{array}$ & $\begin{array}{l}81.49 \\
71.51\end{array}$ & $\begin{array}{l}18.51 \\
28.49\end{array}$ & & & & \\
\hline & & & & & & $12 \%$ & $2 \%$ & $8 \%$ & $2 \%$ \\
\hline
\end{tabular}

In totaal is het werken in deeltijd met $12 \%$ toegenomen. Hiervan kan $2 \%$ worden toegeschreven aan de verschuiving in de werkgelegenheidstructuur (er zijn meer vrouwen in de organisatie komen werken). Het grootste deel $(8 \%)$ wordt veroorzaakt door het feit dat zowel mannen als vrouwen meer in deeltijd zijn gaan werken. De laatste $2 \%$ tenslotte is niet eenduidig toe te wijzen aan structuurverandering, dan wel deeltijd-effect, maar is een gecombineerd effect. 


\section{SCENARIO}

In de vorige hoofdstukken werden indicatoren en technieken gepresenteerd waarmee de gegevens in gecomprimeerde vorm weergegeven konden worden of bewerkt worden. In dit hoofdstuk gaan we een stap verder. Scenario's kunnen worden gebruikt om mogelijke toekomstige ontwikkelingen te bepalen.

Voorbeeld:

In dit voorbeeld simuleren we de uitkomsten van een (theoretisch) gehanteerd promotiebeleid van een organisatie. We gaan uit van 5 functieniveaus, waarbij intrede alleen geschied in de twee laagste functies en er slechts promoties mogelijk zijn naar het direct hoger liggende niveau. We veronderstellen de volgende doorstroomkansen:

$\begin{array}{lllllll}\text { functie I } & \text { II } & \text { III } & \text { IV } & \text { V } & \text { uittrede } \\ \text { intrede } & 75 \% & 25 \% & & & & \\ \text { I } & 65 \% & \underline{20 \%} & & & & 15 \% \\ \text { II } & & \mathbf{7 0 \%} & \underline{15 \%} & & & 15 \% \\ \text { III } & & & \mathbf{7 5 \%} & \underline{15 \%} & & 10 \% \\ \text { IV } & & & & 85 \% & \underline{10 \%} & 5 \% \\ \text { V } & & & & & 90 \% & 10 \%\end{array}$

Van de 100 intreders komen er 75 in functie I en 25 in functie II terecht. Het promotiebeleid is zodanig dat vanuit functie I -binnen de tijdsperiode van bijvoorbeeld 1 jaar- 20 mensen naar functie II promoveren, terwijl 15 mensen na 1 jaar de organisatie verlaten. De promotiekansen vanuit de verschillende functies worden aangegeven door de onderstreepte cijfers in de tabel.

De gemiddelde verblijfstijd per functiecategorie is dan:

$\begin{array}{lc}\text { Functie } & \text { Verblijfstijd in jaren } \\ \text { I } & 2,9 \\ \text { II } & 3,3 \\ \text { III } & 4 \\ \text { IV } & 6,7 \\ \text { V } & 10\end{array}$

De verblijfstijd in functie 1 kan worden berekend als $1 /(1-0,65)=2.9$ jaar. Vergelijkbare berekeningen kunnen worden gemaakt voor de overige functie-categorieën. De lange verblijfsduur voor de hoogste functiecategorie wordt veroorzaakt door het feit dat er geen promotie meer mogelijk is. Men kan alleen nog uittreden. 
Gaan we uit van de volgende initiële functieverdeling (waarbij de hoogste functiecategorie nu bovenaan staat):

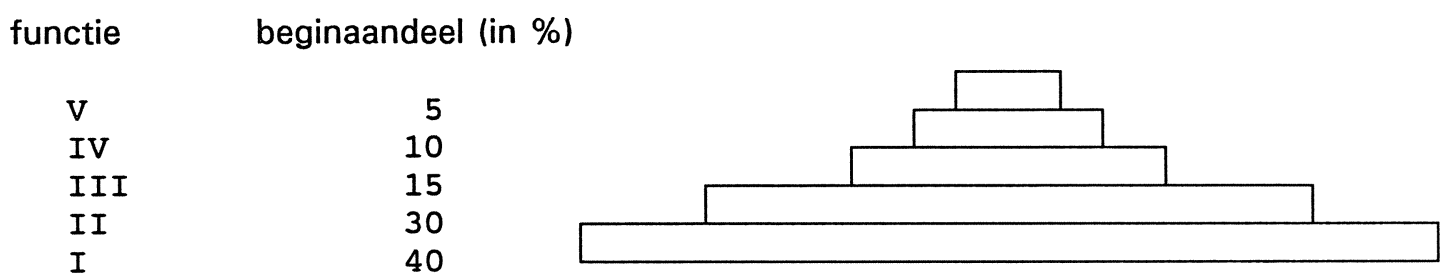

Bij een strak en ongewijzigd promotiebeleid zou de functiestructuur er na 15 jaar als volgt uitzien:

$\begin{array}{ll}\text { V } & 16 \\ \text { IV } & 16 \\ \text { III } & 16 \\ \text { II } & 26 \\ \text { I } & 25\end{array}$

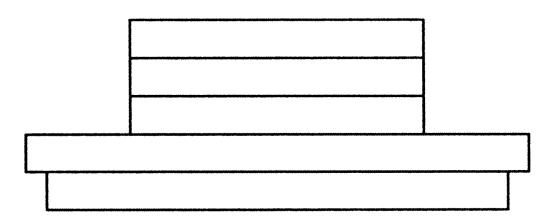

Met name de groei van het hoogste functieniveau opvallend. Dit komt voornamelijk door de gemiddelde verblijfsduur van 10 jaar in functie $V$. Het duurt gemiddeld 17 jaar om vanaf intrede dit hoogste niveau te bereiken.

Dit voorbeeld geeft aan dat indien een op zich redelijk ogend promotiebeleid te star wordt gehanteerd de (hogere) functies als het ware vol lopen, als de instroom in deze functies niet in overeenstemming is met de uitstroom. 


\section{PERSONEELSINDICATOREN}

In dit hoofdstuk wordt een aantal peroneelsindicatoren gepresenteerd. Hierbij gaat het om grootheden die een bepaalde relatie uitdrukken of een statistische waarde die van belang is voor het personeelsbeleid. Op het gebied van personeelsindicatoren zijn veel kengetallen denkbaar. Zo onderscheiden Jansen et.al. (1988) meer dan 150 mogelijke kengetallen. Een aantal van de door hen genoemde voorbeelden zijn opgenomen in bijlage 1. Dit hoofdstuk zal worden beperkt tot enkele wat minder gebruikelijke indicatoren.

\subsection{Structurele promotiekansen}

Definitie:

Structurele promotiekansen worden gedefinieerd als de verhouding in de personeelsomvang van twee opeenvolgende functieniveaus.

In formule: omvang functieniveau $i+1$ /omvang functieniveau $i$

Toepassing:

Promotiekansen worden niet alleen bepaald door iemands individuele prestaties en capaciteiten en het specifieke promotiebeleid, maar ook door de structurele mogelijkheden. Deze structurele mogelijkheden worden enerzijds bepaald door het aantal plaatsen dat kan vrijkomen op een hoger gelegen functieniveau, en anderzijds door het aantal concurrenten dat voor deze vrijgekomen plaatsen in aanmerking komt.

Dit betekent dat de structurele promotiekansen groter worden naarmate het aantal plaatsen op het naast hoger gelegen niveau hoger is en de omvang van het 'eigen' functieniveau $(=$ het aantal concurrenten) lager is.

Voorbeeld:

In 1992 waren de structurele promotiekansen voor de onderscheiden BBRA-schalen bij een aantal ministeries als volgt (zie ook 8.2).

\begin{tabular}{llrrrr}
\hline BBRA & Rijk & BiZa & EZ & VROM & WVC \\
\hline S1-3 & & & & & \\
S4-6 & 2.86 & 4.71 & 4.44 & 10.09 & 1.88 \\
S7-9 & 0.98 & 0.60 & 1.17 & 1.19 & 1.05 \\
S10-12 & 0.55 & 1.47 & 1.03 & 0.89 & 0.99 \\
& 0.29 & 0.46 & 0.30 & 0.29 & 0.32 \\
\hline
\end{tabular}

9. Jansen, K.F., W.H.A. Schafrat, P. Schansman (1988). Sociaal beleid becijferd. Een proeve van kengetallen voor personeel- en organisatiebeleid. Deventer: Kluwer Bedrijfswetenschappen. 
De structurele promotiekansen voor personeel werkzaam in de BBRA-schaal S1-3 bij de Rijksoverheid hebben een waarde 2,86. Deze waarde is als volgt berekend:

$\frac{\text { omvang functieniveau }(i+1)}{\text { omvang functieniveau (i) }}=\frac{46513}{16272}=2,86$

De structurele promotiekansen in deze schaal zijn hoog, aangezien het aantal plaatsen op het naast hoger gelegen niveau hoger is en de omvang van het eigen functieniveau lager is. De kans voor een personeelslid in de schaal S1-3 om door te stromen naar de schaal S4-6 is groot. Er zijn weinig concurrenten op het eigen functieniveau in vergelijking met het aantal mogelijke vrij te komen plaatsen in het naast hoger gelegen niveau. In de schaal S4-6 zijn de structurele promotiekansen aanzienlijk lager $(0,98)$ en doorstromen naar de schaal S7-9 wordt dan ook moeilijker.

Hieruit blijkt een aantal opvallende zaken. In zijn algemeenheid nemen de structurele promotiekansen bij het Rijk bij hogere functieniveaus af. Er zijn echter belangrijke verschillen tussen ministeries. Met name Binnenlandse Zaken vertoont een afwijkend patroon met relatief lage structurele promotiekansen voor de BBRA-schaal 4-6 en relatief hoge kansen voor BBRA 7-9 en 10-12. Het ministerie van VROM kenmerkt zich door zeer hoge structurele promotiekansen voor de laagste BBRA-schaal, terwijl WVC hier juist relatief lage kansen laat zien.

\subsection{Personeelsturnover}

Definitie:

De personeelsturnover wordt gedefinieerd als de wortel uit het product van instroomratio en uitstroomratio.

In formule:

Personeelsturnover $=\sqrt{\frac{I_{t}}{W P_{t}} * \frac{U_{t}}{W P_{t}}}$

waarbij:

$\mathrm{I}_{\mathrm{t}} \quad=$ totale instroom in jaar $\mathrm{t}$

$U_{t} \quad=$ totale uitstroom in jaar $t$

$W P_{t}=$ aantal werkzame personen in jaar $t$

Toepassing:

De combinatie van in- en uitstroomcijfers in een personeelturnoverratio geeft inzicht in de snelheid waarmee het personeelsbestand wordt vernieuwd. Een (te) lage ratio kan wijzen op het gevaar van verstarring en mogelijke veroudering van aanwezige kwalificaties, een (te) hoge ratio kan duiden op het verlies aan ervaring in de organisatie.

Voorbeeld:

Hieronder zijn in een aantal grafieken de personeelturnoverratio's weergegeven per BBRA-niveau voor de gehele overheid en voor een aantal afzonderlijke ministeries. 
$-28-$

Personeelsturnoverratio's
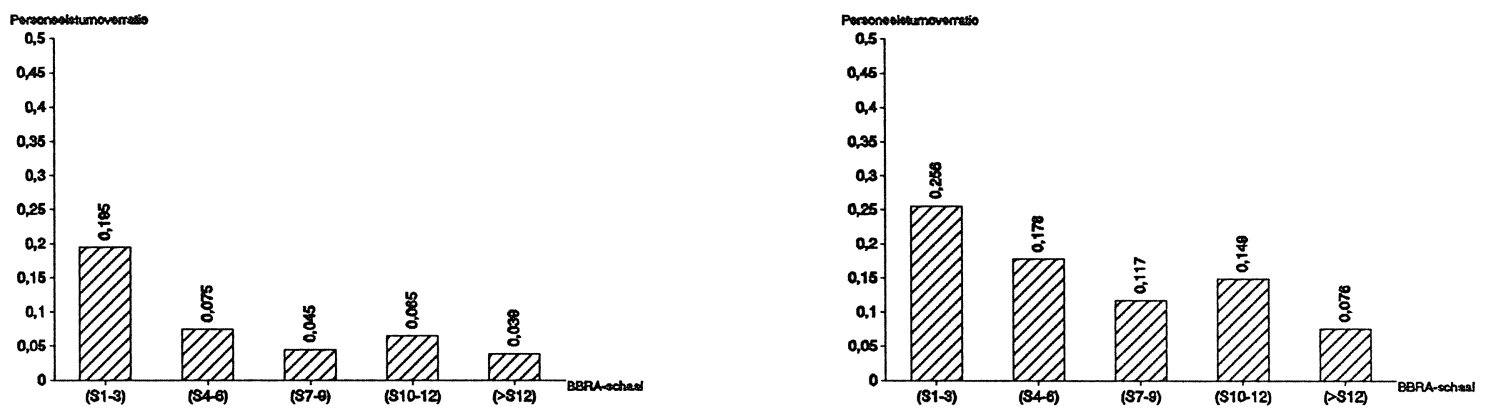

Rijskoverheid

$\mathrm{BiZa}$
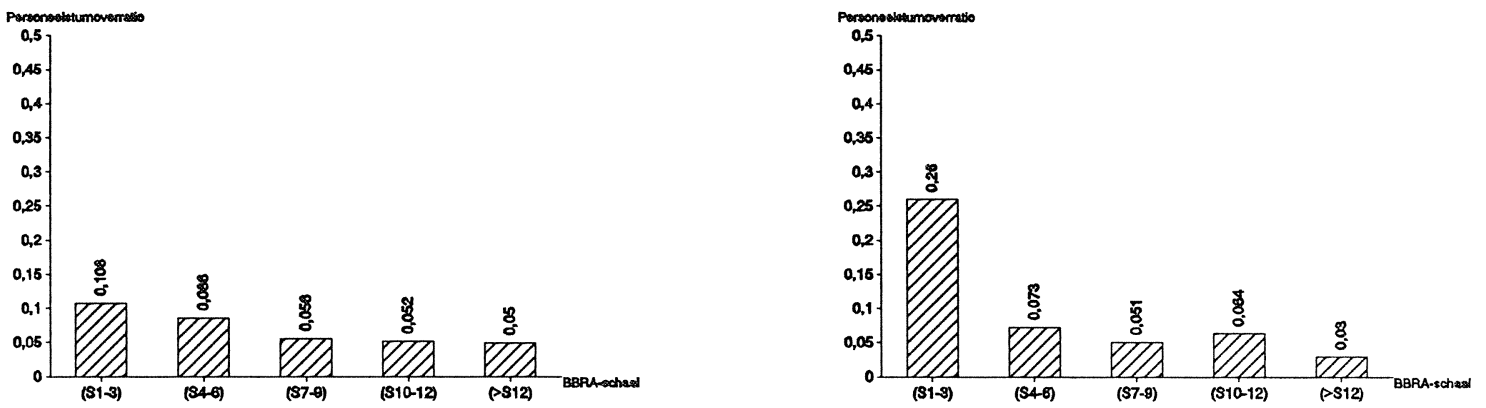

EZ

VROM

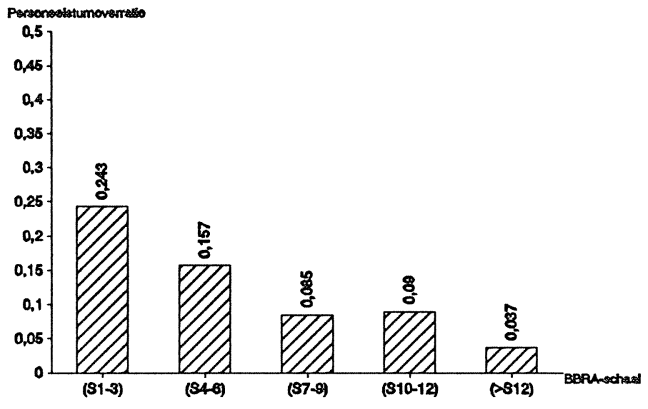

WVC

Een voorbeeldberekening bij de grafische weergave van de personeelsturnoverratio's bij het Rijk:

\begin{tabular}{llll}
\hline BBRA & Instroom & Uitstroom & Eindstand \\
\hline $\mathrm{S} 1-3$ & 3352 & 3005 & 16272 \\
\hline
\end{tabular}


De instroomratio voor $\mathrm{S} 1-3$ is in dat geval $3352 / 16272=0,21$. De uitstroomratio bedraagt $3005 / 16272=0,18$. De turnoverratio bedraagt $\sqrt{0,21 \times 0,18}=0.195$.

Duidelijk blijkt dat de personeelsturnoverratio het hoogst is bij het laagste salarisniveau (BBRA 1-3). Er zijn ook duidelijke verschillen per ministerie. De ratio's bij VROM wijken het minst af van die voor de gehele rijksoverheid. Bij BiZa liggen de ratio's duidelijk boven het gemiddelde. Bij EZ lopen de ratio's van de verschillende salarisschalen het minst uiteen.

\subsection{Uitbreidings- en vervangingsvraag}

Definitie:

De uitbreidingsvraag is het verschil in de totale werkgelegenheid op twee opeenvolgende tijdstippen.

In formule:

waarbij:

$U V_{t+1}=$ uitbreidingsvraag in jaar $t+1$ t.o.v. jaar $t$

$\mathrm{WP}_{\mathrm{t}} \quad=$ aantal werkzame personen in jaar $\mathrm{t}$

De vervangingsvraag is gelijk aan de totale instroom verminderd met de uitbreidingsvraag, indien er sprake is van groei van de werkgelegenheid. Indien er sprake is van een gelijkblijven of daling van de werkgelegenheid, is de vervangingsvraag gelijk aan de totale instroom.

In formule:

bij groei:

$V V_{t+1}=\frac{I_{t+1}}{W P_{t}} * 100 \%-U V_{t+1}=\frac{I_{t+1}-W P_{t+1}+W P_{t}}{W P_{t}} * 100 \%$

waarbij:

$V V_{t+1}=$ vervangingsvraag in jaar $t+1$

$\mathrm{I}_{\mathrm{t}+1} \quad=$ instroom in jaar $\mathrm{t}+1$

$\mathrm{WP}_{\mathrm{t}} \quad=$ aantal werkzame personen in jaar $\mathrm{t}$

bij gelijkblijven of daling:

$V V_{t+1}=\frac{l_{t+1}}{w p_{t}} * 100 \%$

Toepassing:

De totale instroom in een organisatie kan uiteen worden gelegd in twee componenten. De ene component wordt veroorzaakt door uitbreiding of krimp van de organisatie. Deze uitbreidingsbehoefte heeft te maken met de omzet en de productiviteit van een organisatie. De andere component heeft betrekking op de vervanging van personeel door nieuw personeel. Deze vervangingsbehoefte wordt gestuurd door uittrede van personeel als gevolg van pensionering, mobiliteit, ziekte e.d. Voor een organisatie is het van belang om het relatieve aandeel van beide componenten in de instroom te weten. 
Voorbeeld:

In 1993 bedroeg de uitbreidings- en vervangingsvraag bij de rijksoverheid en een aantal ministeries het volgende.

\begin{tabular}{lrrrrr}
\hline & Rijk & BiZa & EZ & VROM & WVC \\
\hline Instroom 1992 & 9823 & 295 & 264 & 386 & 921 \\
Werkzame personen 1992 & 140967 & 2354 & 5298 & 7363 & 7537 \\
Werkzame personen 1991 & 142885 & 2491 & 5499 & 7513 & 7549 \\
& & & & $-2.0 \%$ & $-0.2 \%$ \\
Uitbreidingsvraag & $-1.3 \%$ & $-5.5 \%$ & $-3.7 \%$ & $5.1 \%$ & $12.2 \%$ \\
Vervangingsvraag & $6.9 \%$ & $11.8 \%$ & $4.8 \%$ & & \\
\hline
\end{tabular}

Een voorbeeldberekening voor het Rijk:

$\begin{array}{lr}\text { Instroom } 1992 & 9823 \\ \text { Werkzame personen } 1992 & 140967 \\ \text { Werkzame personen } 1991 & 142885\end{array}$

Uitbreidingsvraag:

$\frac{W P 1992-W P 1991}{W P 1991} \cdot 100 \%=\frac{(140967-142885)}{142885} \cdot 100 \%=-1,34 \%$

Aangezien de werkgelegenheid in 1992 gedaald is ten opzichte van 1991 is de vervangingsvraag:

$\frac{\text { Instroom } 1992}{\text { WP } 1991} \cdot 100 \%=6,87 \%$

Voor het Rijk is de uitbreidingsvraag in $1992-1,3 \%$. Dit wil zeggen dat de werkgelegenheid bij het Rijk in 1992 met 1,3\% is afgenomen ten opzichte van 1991. De vervangingsvraag voor het Rijk in 1992 is 6,9\%. Dit houdt in dat er vervanging nodig is voor $6,9 \%$ van het personeelsbestand in 1991.

$\mathrm{Bij} \mathrm{BiZa}$ is de werkgelegenheid sterk afgenomen met ruim $5 \%$. Bij $\mathrm{WVC}$ is de totale omvang van de werkgelegenheid ongeveer gelijk gebleven. Niettemin is bij beide ministeries de vervangingsvraag als gevolg van pensionering, uittrede e.d. ongeveer gelijk: zo'n $12 \%$. Deze vervangingsvraag is twee keer zo hoog als van de ministeries van EZ en VROM. 


\subsection{Performance indicator}

Definitie:

Een performance indicator is een maatstaf die aangeeft hoe goed een (deel van een) organisatie presteert op enkele speerpunten van het personeelsbeleid in vergelijking met de gemiddelde prestaties op die speerpunten.

In formule:

$T P_{a}=\sum_{i=1}^{m} \frac{P_{a, i} / P_{t o t, i}}{m}$

waarbij:

$\mathrm{TP}_{\mathrm{a}}=$ totale performance van organisatie a

$\mathrm{P}_{\mathrm{a}, \mathrm{i}} \quad$ = performance van organisatie a op indicator $\mathrm{i}$

$P_{\text {tot, } i}=$ performance van alle organisaties op indicator $i$

$\mathrm{m} \quad=$ aantal indicatoren

$\sum_{i}^{m}$ betekent dat sommatie plaats vindt over alle indicatoren 1 tot en met $m$

Toepassing:

Performance indicatoren kunnen goed gebruikt worden bij de evaluatie van organisaties op het gebied van speerpunten in het personeelsbeleid.

Voorbeeld:

Uit het jaarboek Overheid en Arbeidsmarkt 1993 zijn de volgende speerpunten van personeelsbeleid ontleend:

- het percentage vrouwen dat werkzaam is in de organisatie

- het percentage vrouwen dat werrkzaam is in schaal 10 of hoger

- het percentage minderheden dat werkzaam is in de organisatie

- het ziekteverzuimpercentage

- het percentage gehandicapte werknemers binnen de organisatie (WAGWER)

In onderstaande tabel is voor een aantal ministeries de perfomance op deze speerpunten uitgerekend. Daarbij is de afwijking van het gemiddelde ziektepercentage gespiegeld, zodat elke indicator in dezelfde richting wijst: hoe hoger, hoe beter de performance.

\begin{tabular}{lrrrrr}
\hline & Rijk & BiZa & EZ & VROM & WVC \\
\hline \% vrouwen & 28.5 & 43.0 & 29.5 & 27.1 & 40.6 \\
gemiddelde $=1$ & 1.0 & 1.5 & 1.0 & 1.0 & 1.4 \\
\% vrouwen in > S10 & 15.7 & 24.3 & 11.3 & 14.5 & 24.5 \\
gemiddelde $=1$ & 1.0 & 1.5 & 0.7 & 0.9 & 1.6 \\
\% minderheden & 29.0 & 28.0 & 27.0 & 28.0 & 8.0 \\
gemiddelde $=1$ & 1.0 & 1.0 & 0.9 & 1.0 & 0.3 \\
\% ziekteverzuim & 6.8 & 5.0 & 7.4 & 6.9 & 4.8 \\
gemiddelde $=1$ & 1.0 & 0.7 & 1.1 & 1.0 & 0.7 \\
gespiegeld & 1.0 & 1.3 & 0.9 & 1.0 & 1.3 \\
\% wagwer & 2.8 & 4.9 & 2.9 & 1.5 & 2.3 \\
gemiddelde $=1$ & 1.0 & 1.7 & 1.0 & 0.5 & 0.8 \\
performance indicator & 1.0 & 1.4 & 0.9 & 0.9 & 1.1 \\
\hline
\end{tabular}


Voor het \% vrouwen bij het Ministerie van Binnenlandse Zaken staat de indicator op 1,5. Deze indicator wil zeggen dat het percentage vrouwen dat bij dit ministerie werkt 1,5 maal zo groot is als het percentage vrouwen dat bij de Rijksoverheid werkt. De indicator is als volgt berekend:

$\frac{\% \text { vrouwen bij Biza }}{\% \text { vrouwen bij Rijk }}=\frac{43}{28,5}=1,5$

De performance-indicator van het Ministerie van Binnenlandse Zaken is het gemiddelde van de vijf indicatoren:

$\frac{(1,5+1,5+1,0+1,3+1,7)}{5}=1,4$

5

De totale performance van dit ministerie ligt dus $40 \%$ boven de performance van de Rijksoverheid.

Duidelijk blijkt dat BiZa een heel goede totale performance heeft. Ook op elk van de afzonderlijke onderdelen scoort ze beter dan gemiddeld met uitzondering van het percentage minderheden dat gelijk is aan het gemiddelde. WVC heeft een gemiddelde performance: weliswaar scoort ze enerzijds goed op de indicatoren met betrekking tot het percentage vrouwen en het ziekteverzuim, maar daar staan zeer lage scores met betrekking tot het percentage Wagwer en vooral het percentage minderheden tegenover. 


\section{AFBEELDINGEN}

Gegevens kunnen enerzijds overzichtelijk gepresenteerd worden door een of andere vorm van datareductie toe te passen. Anderzijds kan ook gewerkt worden met allerlei grafische presentaties, zoals lijn- en staafdiagrammen, pie-charts e.d. In dit hoofdstuk wordt een aantal afbeeldingen gepresenteerd die in de huidige jaarboeken nog niet voorkomen.

\subsection{Functie-opbouw}

De informatie over de verdeling van personeel over de verschillende BBRA-niveau's zou inzichtelijk als volgt kunnen worden gepresenteerd:

Functie-opbouw in 1992:

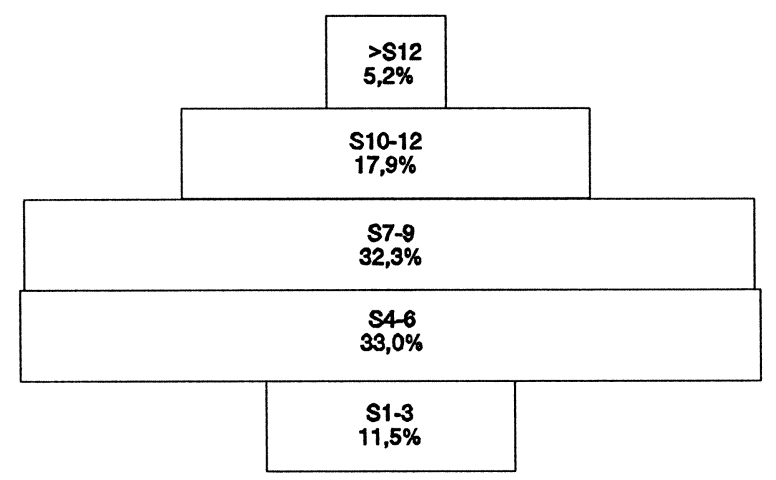

Functie-opbouw in 1982:

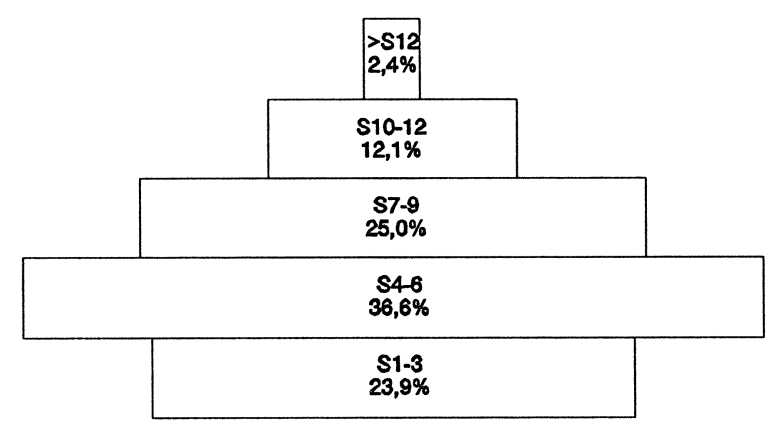

Weergegeven is de verdeling over de BBRA-niveaus in 1992 en 1982 voor het totale rijksoverheidspersoneel. De breedte van de balken corresponderen met de aandelen van de betreffende BBRA-schalen in het totale bestand in de betreffende jaren. Duidelijk is te zien dat de organisatie is veranderd van een duidelijke pyramide-structuur naar een ui-vorm, met een sterke uitbreiding van het middenkader ten koste van de laagste niveaus.

\subsection{Promotiekokers}

De structurele promotiekansen van een organisatie (zie paragraaf 7.1.) kunnnen eenvoudig als een promotiekoker worden weergegeven. 
$-34-$

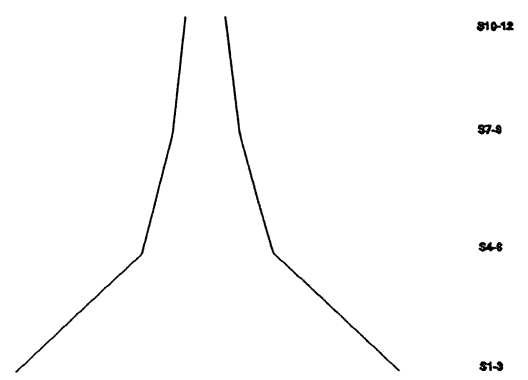

Rijksoverheid
.
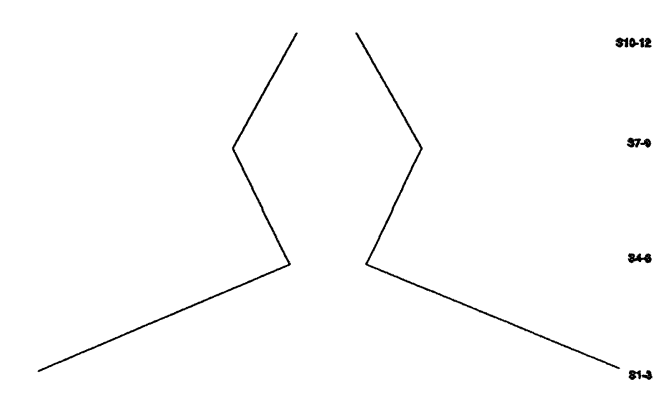

$\mathrm{BiZa}$

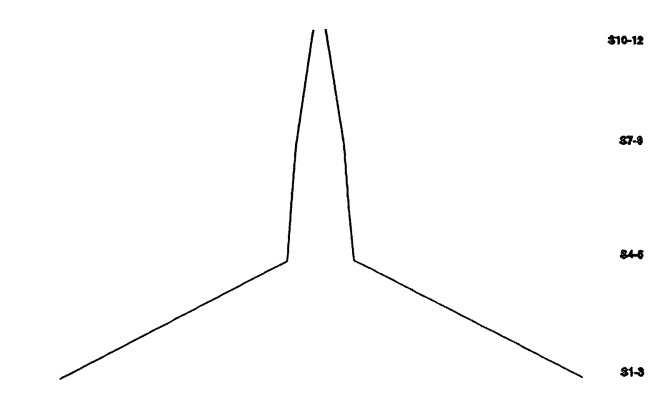

VROM

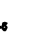

$-$

EZ
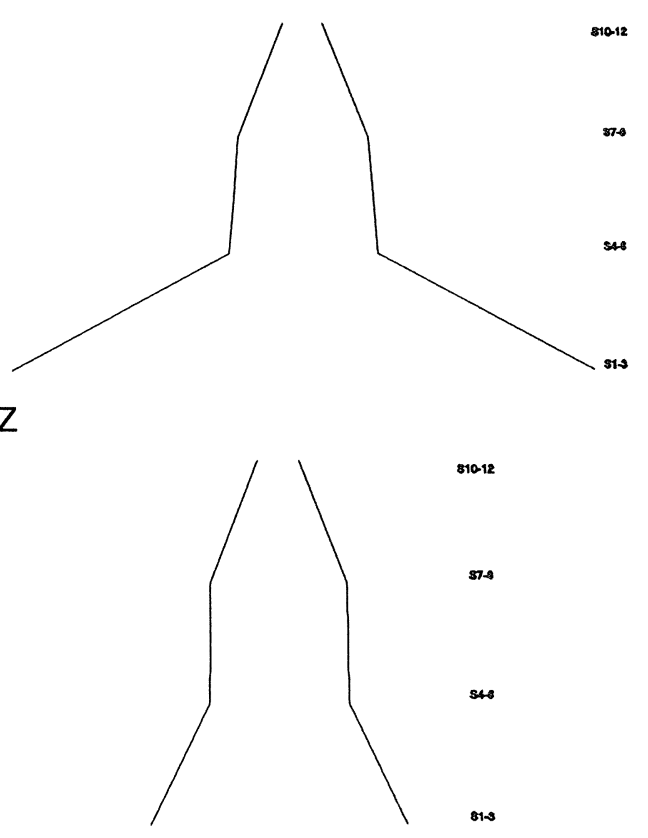

WVC
10.12

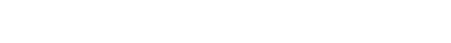




\subsection{Afwijkingen van het gemiddelde}

Afwijkingen in een bepaalde verdeling ten opzichte van het gemiddelde kunnen eenvoudig als volgt worden weergegeven.
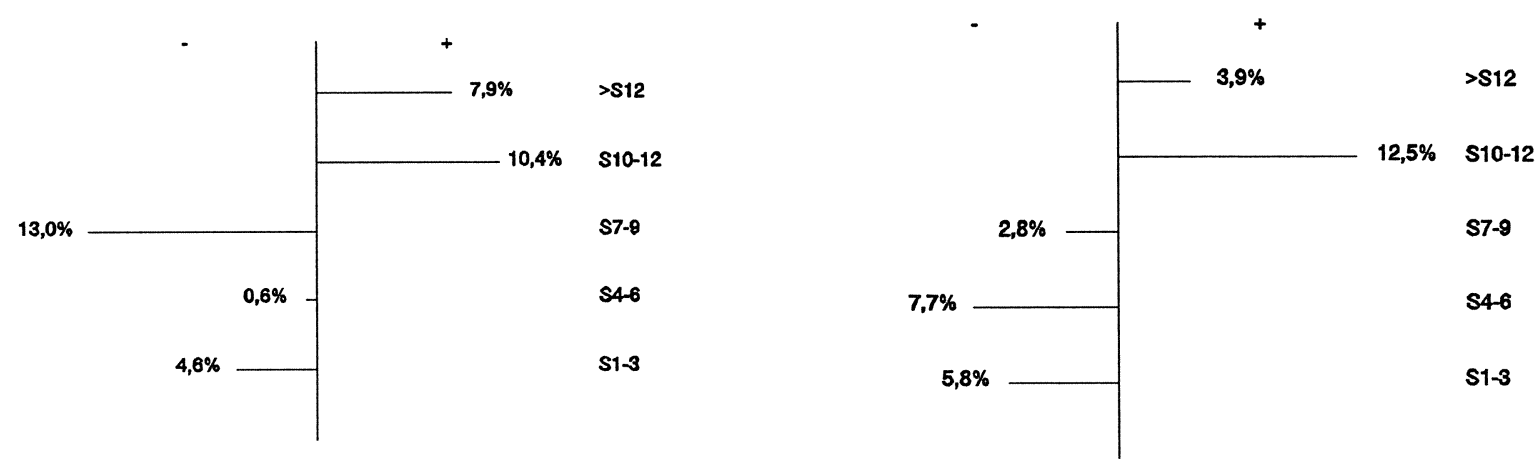

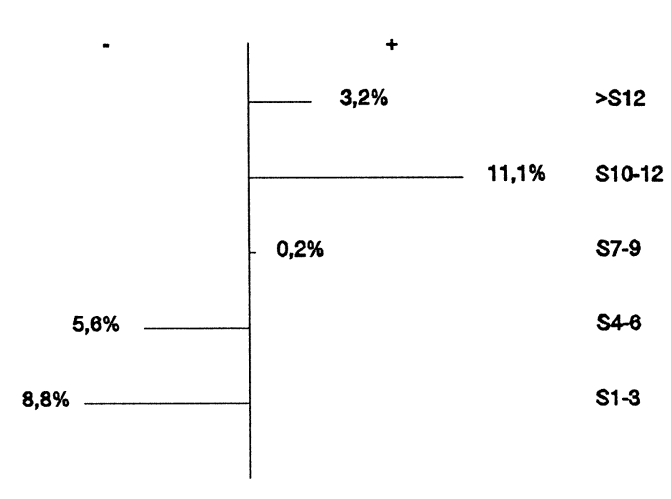

VROM

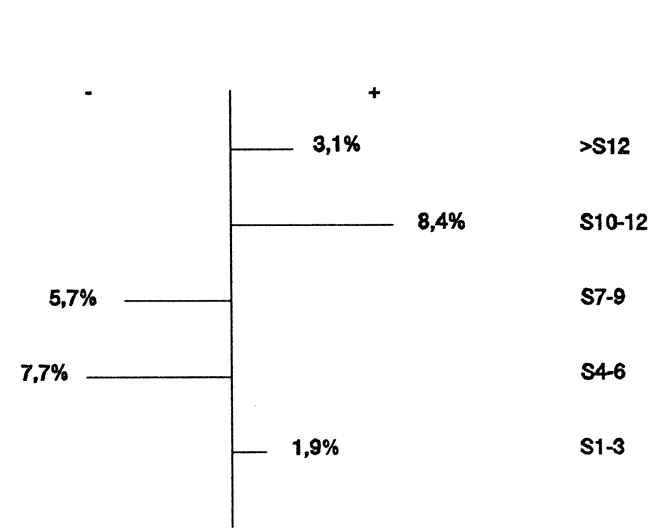

WVC

In de grafieken wordt de functie-opbouw in 1992 van een aantal ministeries gepresenteerd als afwijking van de functie-opbouw bij de totale overheid (zie 8.1.). Duidelijk is te zien dat bij de onderscheiden ministeries een relatieve oververtegenwoordiging bestaat van de hogere functieniveaus en dat bij BiZa met name S 7-9 ondervertegenwoordigd is.

\subsection{Multi Dimensional Scaling}

De performance van afzonderlijke ministeries op de verschillende taakstellingen (zie 7.4) kan met behulp van Multi Dimensional Scaling inzichtelijk als volgt worden weergegeven: 


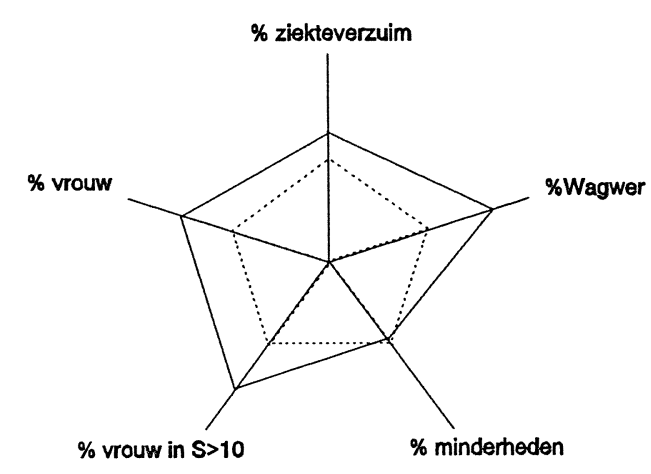

$\mathrm{BiZa}$

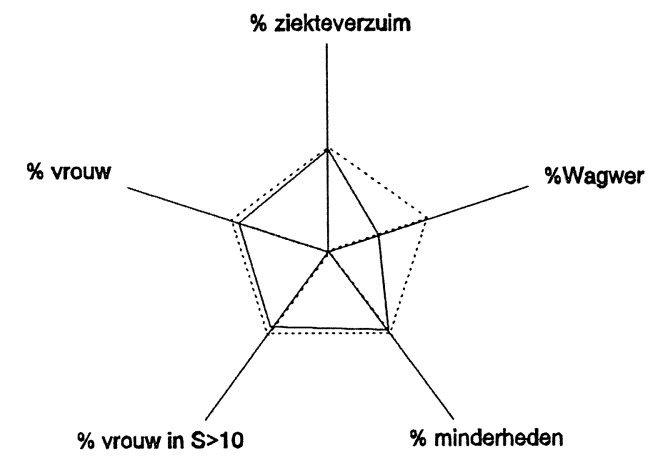

VROM

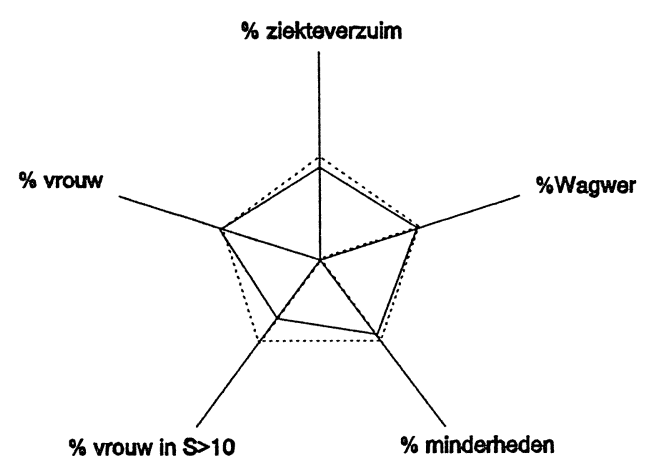

EZ

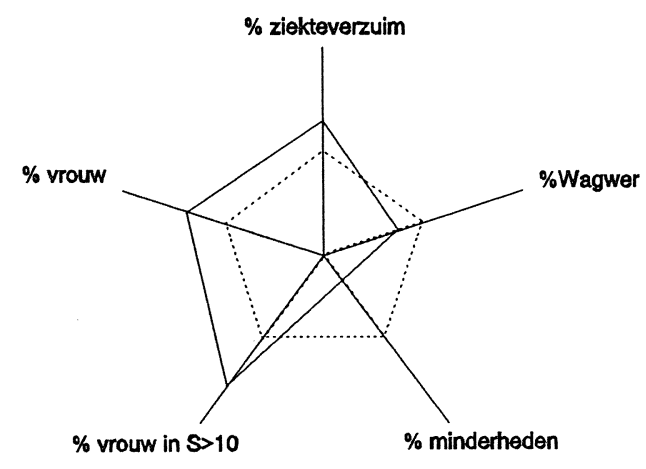

WVC

De verschillende hoeken van de hier weergegeven pentagrammen representeren elk een andere indicator. De gestippelde lijn geeft de gemiddelde performance op deze indicatoren weer. Deze ligt op een vaste afstand 1 van het middelpunt. De zwarte lijn geeft de performance van het betreffende ministerie. Wanneer de zwarte lijn buiten de stippellijn valt, presteert een ministerie op de betreffende indicator beter dan gemiddeld. Duidelijk is weer te zien dat BiZa op alle indicatoren goed scoort, terwijl WVC een gemixt beeld laat zien.

\subsection{Lorenz-curve}

De scheefheid van een verdeling, bijvoorbeeld de inkomensverdeling, kan als volgt in een zogenaamde Lorenz-curve worden weergegeven: 


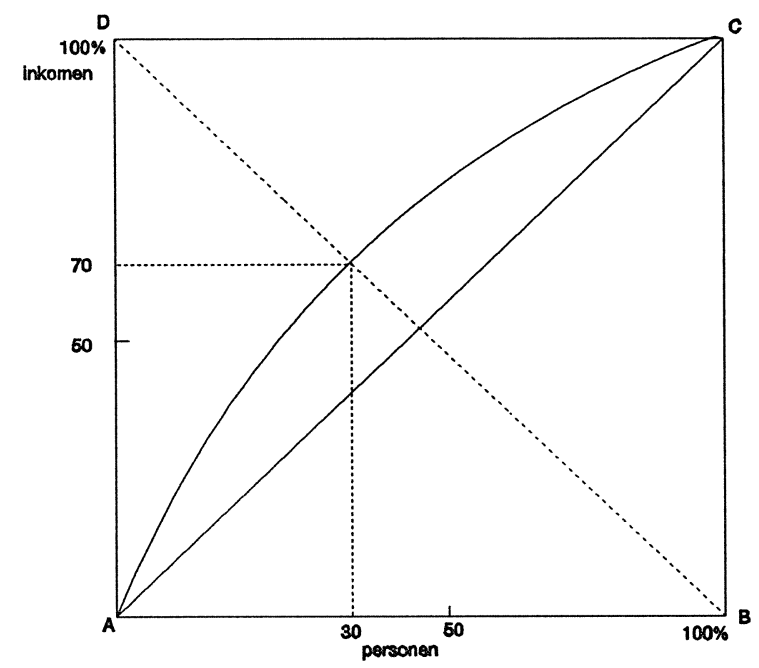

De interpretatie van de Lorenz-curve is als volgt. De diagonaal AC geeft de situatie weer waarin iedereen evenveel verdient. Nauwkeuriger geformuleerd: het betreft de situatie waarin elk persoon een even groot aandeel van de totale salarislast ontvangt. Dat wil zeggen dat $10 \%$ van het totaal aantal werkenden ook $10 \%$ van de totale salarislast ontvangt, $50 \%$ van de werkenden ontvangt $50 \%$ van de totale salarislast etc. De curve AC geeft de feitelijke inkomensverdeling weer. Naarmate deze krommer is, is de verdeling meer ongelijk. In dit voorbeeld verdienen $30 \%$ van de werkenden met elkaar $70 \%$ van de totale salarislast. De plaats waar de curve AC de diagonaal DB snijdt is een goede indicator voor de mate van ongelijkheid. 


\title{
BIJLAGE 1. ANDERE PERSONEELSINDICATOREN
}

\author{
Jansen et.al $(1988)^{10}$ onderscheiden in een lexicon van kengetallen voor het personeelsbeleid \\ meer dan 150 mogelijke personeelsindicatoren. Een selectie hiervan wordt hier weergegeven.
}

\begin{tabular}{|c|c|c|}
\hline Naam kengetal & beschrijving & berekeningswijze \\
\hline vacature-ratio & $\begin{array}{l}\text { percentage vacatures op } \\
\text { het totale bestand }\end{array}$ & $\frac{\text { aantal fte vacatures op tijdstip } t}{\text { aantal fte personeelssterkte }+ \text { vacatures op tijdstip } t}$ \\
\hline $\begin{array}{l}\text { interne mobiliteits- } \\
\text { ratio }\end{array}$ & $\begin{array}{l}\text { het aantal mensen dat per } \\
\text { jaar verandert van functie } \\
\text { of standplaats binnen de } \\
\text { organisatie }\end{array}$ & $\frac{\text { aantal overplaatsingen, promoties, demoties }}{\text { totaal aantal medewerkers }}$ per jaar \\
\hline direct/indirect & $\begin{array}{l}\text { aantal direct aan het produkt } \\
\text { toe te rekenen medewerkers } \\
\text { in verhouding tot het aantal } \\
\text { leiding-, staf- en } \\
\text { administratieve medewerkers }\end{array}$ & $\frac{\text { aantal direct medewerkers }}{\text { totaal indirecte medewerkers }}$ \\
\hline $\begin{array}{l}\text { gemiddelde duur } \\
\text { dienstverband }\end{array}$ & $\begin{array}{l}\text { gemiddeld aantal dienstjaren } \\
\text { dat medewerkers werkzaam } \\
\text { zijn alvorens te vertrekken }\end{array}$ & $\frac{\text { duur dienstverband per medewerker }}{\text { totaal aantal medewerkers }}$ \\
\hline $\begin{array}{l}\text { gemiddelde } \\
\text { functieduur }\end{array}$ & $\begin{array}{l}\text { gemiddeld aantal jaren in de } \\
\text { relevante of huidige functie }\end{array}$ & $\frac{\text { aantal jaren in relevante/huidige functie per medewerker }}{\text { totaal aantal medewerkers }}$ \\
\hline prestatiebeloning & $\begin{array}{l}\text { hantering van prestatie- } \\
\text { beloning in relatie tot vaste } \\
\text { beloning }\end{array}$ & $\begin{array}{l}\text { uitgekeerd salaris in de vorm van premies, } \\
\text { prestatietoeslag, overwerk e.d. } \\
\text { totale salarissom }\end{array}$ \\
\hline $\begin{array}{l}\text { kosten van 'fringe } \\
\text { benefits' }\end{array}$ & $\begin{array}{l}\text { mate waarin de arbeids- } \\
\text { kosten exclusief sociale } \\
\text { lasten uitstijgen boven de } \\
\text { loonsom }\end{array}$ & $\begin{array}{l}\Sigma \text { arbeidskosten inclusief alle vergoedingen } \\
\text { e.d. doch exclusief sociale premies per jaar } \\
\begin{array}{c}\Sigma \text { primaire bruto-jaarsalarissen (=totale bruto- } \\
\text { inkomens) }\end{array}\end{array}$ \\
\hline $\begin{array}{l}\text { arbeidskosten- } \\
\text { opslag }\end{array}$ & $\begin{array}{l}\text { ontwikkeling arbeidskosten } \\
\text { t.o.v. inkomens van de } \\
\text { medewerkers }\end{array}$ & $\begin{array}{l}\Sigma \text { totaal van de arbeidskosten inclusief } \\
\frac{\text { sociale premies }}{\Sigma \text { primaire bruto-jaarsalarissen }} \times 100 \%\end{array}$ \\
\hline $\begin{array}{l}\text { ratio voor kort } \\
\text { en lang ziekte- } \\
\text { verzuim }\end{array}$ & $\begin{array}{l}\text { aandeel kort verzuim }(<10 \\
\text { dagen) als } \% \text { van het totale } \\
\text { verzuim }\end{array}$ & $\frac{\text { aantal kort-verzuimgevallen }}{\text { totaal aantal verzuimgevallen }} \times 100 \%$ \\
\hline $\begin{array}{l}\text { opleidings- } \\
\text { rendement }\end{array}$ & $\begin{array}{l}\text { hoeveel functiegerichte en } \\
\text { door het bedrijf bekostigde } \\
\text { opleidingen, die worden be- } \\
\text { gonnen, worden ook inder- } \\
\text { daad door medewerkers } \\
\text { succesvol afgemaakt? }\end{array}$ & $\frac{\text { aantal met een diploma afgeronde opleidingen per jaar }}{\text { aantal gevolgde opleidingen in dat jaar }}$ \\
\hline
\end{tabular}

10. Jansen, K.F., W.H.A. Schafrat, P. Schansman (1988). Sociaal beleid becijferd. Een proeve van kengetallen voor personeel- en organisatiebeleid. Deventer: Kluwer Bedrijfswetenschappen. 
$-39-$

\begin{tabular}{|c|c|c|}
\hline $\begin{array}{l}\text { opleidings- } \\
\text { investering }\end{array}$ & $\begin{array}{l}\text { omvang van het geïn- } \\
\text { vesteerde budget aan interne } \\
\text { en externe opleiding }\end{array}$ & $\frac{\text { opleidingsbudget }}{\text { loonsom }} \times 100 \%$ \\
\hline $\begin{array}{l}\text { opleidings- } \\
\text { inspanning }\end{array}$ & $\begin{array}{l}\text { omvang van de door de orga- } \\
\text { nisatie ingeleverde inspan- } \\
\text { ning tot opleiding }\end{array}$ & $\frac{\text { aantal werkdagen besteed aan scholing en opleiding }}{\text { totaal aantal werkdagen }}$ \\
\hline $\begin{array}{l}\text { beroep op externe } \\
\text { arbeidsmarkt }\end{array}$ & $\begin{array}{l}\text { het aantal functies waarvoor } \\
\text { een beroep op de externe ar- } \\
\text { beidsmarkt noodzakelijk is in } \\
\text { verhouding tot het aantal in- } \\
\text { terne overplaatsingen }\end{array}$ & $\frac{\text { aantal extern aangetrokken kandidaten }}{\text { aantal intern }+ \text { extern aangetrokken kandidaten }}$ \\
\hline carrièrelengte & $\begin{array}{l}\text { aantal loopbaanstappen } \\
\text { voor managementfunctie }\end{array}$ & $\begin{array}{l}\text { gemiddeld aantal afgelegde interne loopbaanstappen per } \\
\text { medewerker in management-functie }\end{array}$ \\
\hline \multirow[t]{2}{*}{$\begin{array}{l}\text { 'make or buy'- } \\
\text { ratio }\end{array}$} & $\begin{array}{l}\text { voor hoeveel sleutelfuncties } \\
\text { leidt de organisatie zelf op }\end{array}$ & $\begin{array}{c}\text { aantal van buiten aangetrokken sleutelfunctionarissen } \\
\text { per jaar }\end{array}$ \\
\hline & $\begin{array}{l}\text { (via } \mathrm{MD} \text { ) en hoeveel mensen } \\
\text { worden ingekocht via de ar- } \\
\text { beidsmarkt }\end{array}$ & totaal aantal sleutelfuncties \\
\hline $\begin{array}{l}\text { vergrijzing } \\
\text { management }\end{array}$ & $\begin{array}{l}\text { gemiddelde leeftijd } \\
\text { management }\end{array}$ & $\frac{\text { som leeftijd van alle managers }}{\text { aantal managers }}$ \\
\hline $\begin{array}{l}\text { positie van de } \\
\text { vrouw }\end{array}$ & $\begin{array}{l}\text { aantal vrouwen in leiding- } \\
\text { gevende posities binnen de } \\
\text { organisatie }\end{array}$ & $\frac{\text { aantal vrouwen in leidinggevende functies }}{\text { totaal aantal leidinggevende functies }}$ \\
\hline
\end{tabular}

